\title{
Learn from the Past, Prepare for the Future: Impacts of Education and Experience on Disaster Preparedness in the Philippines and Thailand
}

\author{
ROMAN HOFFMANN ${ }^{\mathrm{a}, \mathrm{b}}$ and RAYA MUTTARAK ${ }^{\mathrm{a}, \mathrm{c}, *}$ \\ ${ }^{a}$ Wittgenstein Centre for Demography and Global Human Capital (IIASA, VID/ÖAW and WU), Vienna \\ Institute of Demography, Austrian Academy of Sciences, Austria \\ ${ }^{\mathrm{b}}$ Department of Economics, University of Vienna, Austria \\ ${ }^{c}$ School of International Development, University of East Anglia, UK
}

\begin{abstract}
Summary. - This study aims at understanding the role of education in promoting disaster preparedness. Strengthening resilience to climate-related hazards is an urgent target of Goal 13 of the Sustainable Development Goals. Preparing for a disaster such as stockpiling of emergency supplies or having a family evacuation plan can substantially minimize loss and damages from natural hazards. However, the levels of household disaster preparedness are often low even in disaster-prone areas. Focusing on determinants of personal disaster preparedness, this paper investigates: (1) pathways through which education enhances preparedness; and (2) the interplay between education and experience in shaping preparedness actions. Data analysis is based on face-to-face surveys of adults aged $\geq 15$ years in Thailand $(N=1,310)$ and the Philippines ( $N=889$, female only). Controlling for socio-demographic and contextual characteristics, we find that formal education raises the propensity to prepare against disasters. Using the KHB method to further decompose the education effects, we find that the effect of education on disaster preparedness is mainly mediated through social capital and disaster risk perception in Thailand whereas there is no evidence that education is mediated through observable channels in the Philippines. This suggests that the underlying mechanisms explaining the education effects are highly context-specific. Controlling for the interplay between education and disaster experience, we show that education raises disaster preparedness only for those households that have not been affected by a disaster in the past. Education improves abstract reasoning and anticipation skills such that the better educated undertake preventive measures without needing to first experience the harmful event and then learn later. In line with recent efforts of various UN agencies in promoting education for sustainable development, this study provides a solid empirical evidence showing positive externalities of education in disaster risk reduction.

(c) 2017 The Authors. Published by Elsevier Ltd. This is an open access article under the CC BY-NC-ND license (http://creativecommons.org/ licenses/by-nc-nd/4.0/).
\end{abstract}

Key words - Disaster preparedness, Disaster resilience, Education, Experience, Low- and middle-income countries, Southeast Asia

\section{INTRODUCTION}

In the past years the world has witnessed a significant global increase in the intensity and frequency of extreme weather events such as floods, droughts, and tropical storms, which are expected to increase even further in a future warmer climate (Field et al., 2012). Since 1975, the number of reported disaster incidents has risen more than threefold: from 65 reported incidents in 1975 to 344 in 2014. In the year 2014 alone, disasters caused a worldwide damage of US\$ 98.43 billion with more than 140 million persons affected (Centre for Research on the Epidemiology of Disasters, 2015; EM-DAT, 2015). Heavily exposed low- and middle-income countries, in particular, carry a large share of the human and economic burden. Undoubtedly, disaster risk reduction is a fundamental component of social and economic development, especially in order to ensure sustainability of development in the future. Accordingly, one of the urgent targets of Goal 13 of the newly adopted Sustainable Development Goals (SDGs) is to strengthen resilience and adaptive capacity to climate-related hazards, which essentially include reducing disaster risks (UNISDR, 2015).

There has recently been improvements in national disaster risk reduction efforts especially after major disaster events such as the 2004 Indian Ocean Tsunami (Birkmann et al., 2008) or the 2013 Typhoon Haiyan in the Philippines. Indeed, governments' investments in structural mitigation for large buildings or infrastructure, implementation of early warning systems, planned evacuation routes and shelters are effective in preventing loss of life (Andrews \& Quintana, 2015). Nevertheless, disaster risk reduction measures at the national level alone are not sufficient to protect households from the devastating impacts of a disaster. In fact, in time of emergencies-be natural disasters or terrorist attacks - experts recommend the "72 Hour Rule" in which individuals are required to be self-

\footnotetext{
* Funding for this work was made possible by the Austrian Science Fund (FWF): Z171-G11, an Advanced Grant of the European Research Council, "Forecasting Societies Adaptive Capacities to Climate Change" (grant agreement ERC-2008-AdG 230195 FutureSoc) and the Ratchadaphiseksomphot Endowment Fund of Chulalongkorn University for the project "Understanding Social Barriers to Coping with and Adapting to Extreme Climate Events" (Grant agreement number: RES560530150-CC). The project in the Philippines was funded with a research grant from the Vienna University of Economics and Business. The authors would like to gratefully thank their partners in the Philippines and Thailand, most notably the Kasagana-Ka Development Center Inc. (PH) represented by Ms. Maria Anna de Rosas-Ignacio and the College of Population Studies, Chulalongkorn University in particular Dr.Wiraporn Pothisiri (TH), who supported us with the data collection. Final revision accepted: February 12, 2017
} 
sufficient for at least three days following a disaster (Russell, Goltz, \& Bourque, 1995). This is because it takes some time for local government and disaster-relief organizations to mobilize resources to an affected area. Therefore, individual preparedness measures such as stockpiling of food and water, having a first aid kit in the home, or having a family evacuation plan can ensure a proper response to natural hazards. Particularly in low- and middle-income countries where public disaster risk management is relatively underdeveloped, precautionary measures taken by households before a disaster occurs can reduce the risk of loss of life and injuries as well as minimize damage to the property (Shreve \& Kelman, 2014; van der Keur et al., 2016).

Despite the importance of individual preparedness, several studies report relatively low levels of disaster preparedness even in disaster prone areas (Adiyoso \& Kanegae, 2014; Kohn, Eaton, Feroz, Bainbridge, Hoolachan, \& Barnett, 2012). How people can be motivated to take precautionary actions when they have little prior disaster experience has been a fundamental question raised by scholars of risk analysis and risk communication (Harvatt, Petts, \& Chilvers, 2011). Accordingly, in many disaster-prone areas local and national governments and NGOs have put efforts in providing disaster educational programs and emergency trainings in order to raise awareness, promote self-reliance and household preparedness actions. While such educational activities can boost disaster preparedness in some cases (Mishra \& Suar, 2007; Wood, Mileti, Kano, Kelley, Regan, \& Bourque, 2012), many studies have documented the failure of these campaigns in initiating protective actions (Baker, 1980; Paton \& Johnston, 2001; Sims \& Baumann, 1983; Sorensen, 1983). In order to promote household disaster resilience, it is thus crucial to understand underlying factors explaining the adoption of preparedness measures. There are nevertheless relatively few empirical studies on the determinants of disaster preparedness in developing countries (Muttarak \& Pothisiri, 2013).

To this end, this study focuses on examining individual determinants of disaster preparedness in low- and middleincome countries in Southeast Asia, namely, the Philippines and Thailand, which have been affected by major disaster incidents in the past decade. According to the most recent Climate Risk Index, both countries ranked among the top ten of countries worldwide most affected by extreme weather conditions from 1995 to 2014 (Kreft, Eckstein, Dorsch, \& Fischer, 2015). Such disaster experience may raise public awareness and preparedness accordingly. In this paper, we aim to: (1) analyze the role of formal education in shaping an individual's propensity to prepare against disasters and identify mediating channels through which education may influence disaster preparedness; and (2) investigate the importance of past disaster experience and its interplay with education. Theoretically, both factors may determine preparedness through similar mechanisms such as increasing risk perception or knowledge about the devastating consequences of a disaster. Formal education, as a channel through which individuals can "learn" about disaster risks and preventive strategies, may consequently replace disaster experience in promoting preparedness actions.

The remainder of the paper is structured as follows. Section 2 describes determinants of disaster preparedness, presents a conceptual framework for our empirical analysis and discusses the previous literature on education and preparedness behavior. Section 3 introduces the case studies and presents the data and measurement used including the estimation strategy. The descriptive and multivariate results are presented and discussed in Section 4. Section 5 concludes with a summary of the findings and implications of our research.

\section{CONCEPTUAL FRAMEWORK AND PREVIOUS LITERATURE}

\section{(a) Overview of determinants of individual disaster preparedness}

The previous literature has identified various determinants of personal/household disaster preparedness. These can be broadly divided into socio-demographic characteristics, structural/geographical variables and psychosocial factors. In terms of demographic characteristics, generally being married (Reininger et al., 2013; Russell et al., 1995) in middle-age groups (Baker, 2011; Boscarino, Adams, Figley, Galea, \& Foa, 2006; Sattler, Kaiser, \& Hittner, 2000) and having children living in the home (Basolo, Steinberg, Burby, Levine, Cruz, \& Huang, 2009; Eisenman, Zhou, Ong, Asch, Glik, \& Long, 2009) are associated with higher preparedness actions. Likewise, having household members with a disability or health conditions that require special equipment also increase the likelihood of preparedness (Ablah, Konda, \& Kelley, 2009; Eisenman et al., 2009; Muttarak \& Pothisiri, 2013).

While demographic characteristics determine necessities to prepare (e.g., having dependent members in the home), socioeconomic factors influence a household's capability to undertake preparedness actions, among other things. Some preparedness measures such as purchasing disaster insurance or the technical or structural building retrofitting require financial investment. Thus, higher income is associated with higher preparedness levels partly because it enables households to afford to take such actions (Mishra \& Suar, 2007; Murphy, Cody, Frank, Glik, \& Ang, 2009; Phillips, Metz, \& Nieves, 2005). Also, homeowners are more likely to be prepared than renters (Burby, Steinberg, \& Basolo, 2003; Siegel, Shoaf, Afifi, \& Bourque, 2003; Spittal, McClure, Siegert, \& Walkey, 2008). Having invested more time and money in constructing their homes and household goods, homeowners have stronger ties with the property and place of residence while those who rent are more mobile and less focused on the long-term horizon (Harvatt et al., 2011). Socioeconomic constraints thus partially explain the adoption of preparedness actions.

Structural/geographical variables have also been identified to be crucial determinants of disaster preparedness. Longer residence in the community enhances local knowledge about the neighborhood, natural environment, and hazard risks. This in turn increases disaster awareness and promotes the undertaking of preparatory activities (Tanaka, 2005). Similarly, living in or close to the hazard area implies better knowledge about hazard risks and consequently increases preparedness actions (Baker, 2011; Lindell \& Hwang, 2008).

Apart from demographic, socioeconomic and structural/geographical characteristics determining the need and capacity to be prepared, disaster preparedness has also been found to be associated with psychosocial factors including hazard awareness, risk perception, self-efficacy and knowledge. In order for preparedness actions to take place, first people need to be aware of the hazards and consequently perceive them as critical or salient issues within their community. Accordingly, some studies reported that higher levels of perceived risk are associated with increases in preparedness behavior (Martin, Martin, \& Kent, 2009; McNeill, Dunlop, Heath, Skinner, \& Morrison, 2013; Paul \& Bhuiyan, 2010). On the other hand, lack of self-efficacy i.e. beliefs regarding personal capacity to 
act effectively can inhibit individuals to take actions (Lindell \& Whitney, 2000; Paton, Millar, \& Johnston, 2001). Recognizing the role of psychosocial factors is thus fundamental in public campaigns to promote personal disaster preparedness.

\section{(b) Conceptual framework: the role of education in promoting preparedness}

Apart from the above mentioned factors, in this study, we contend that formal education can play a key role in promoting preparedness behavior. Formal education here refers to classroom-based education normally delivered in a systematic way by trained teachers in a structured environment such as a school, college, or university. In this context, formal education is measured as years of schooling assuming that the higher the number of years an individual spent in a formal education setting, the more educated she/he is.

While we focus on the influence of formal education in this study, it is worth noting that other forms of education, which take place outside the classroom, can also play a crucial role in reducing vulnerability to disasters. Whereas formal education is obtained in the hierarchically structured public education system, non-formal education refers to any organized education activity that takes place outside the established formal system such as community education or alternative learning programs (Coombs, Prosser, \& Ahmed, 1973). Examples for such non-formal education initiatives include communitybased disaster trainings and drills, which have been shown to be an effective mean in building local capacities and in raising awareness and resilience of communities (Allen, 2006; Karanci, Aksit, \& Dirik, 2005). Likewise, informal education, which includes learning from daily experience and the educative influences and resources in the environment, can also play a role in promoting disaster risk reduction (Richardson \& Wolfe, 2001). For instance, informal education obtained during childhood through parents or other community members may influence preparedness behavior. At the same time, it has been found that living in a community with a higher level of education significantly increases preparedness actions (Muttarak \& Pothisiri, 2013) suggesting that there is knowledge and skills exchange among community members. Although both non-formal and informal education is relevant to disaster risk reduction, it is beyond the scope of this study to empirically test the impacts of these types of education. Thus, in this paper, we focus primarily on formal education.

In fact, various studies have analyzed the link between formal education and disaster preparedness with mixed results. On the one hand, many studies reported that higher educational attainment enhances preparedness including being prepared for earthquakes (Russell et al., 1995), hurricanes (Baker, Leon, Smith Greenaway, Collins, \& Movit, 2011; Norris, Smith, \& Kaniasty, 1999; Reininger et al., 2013), floods (Lave \& Lave, 1991; Thieken, Kriebich, Müller, \& Merz, 2007), tsunami (Muttarak \& Pothisiri, 2013), terrorism (Bourque, Mileti, Kano, \& Wood, 2012; Eisenman et al., 2009; Lee \& Lemyre, 2009) and general emergency preparedness (A1Rousan, Rubenstein, \& Wallace, 2014; Smith \& Notaro, 2009). On the other hand, a considerable number of studies reported no association between education and preparedness (Faupel, Kelly, \& Petee, 1992; Hausman, Hanlon, \& Seals, 2007; Heller, Alexander, Gatz, Knight, \& Rose, 2005; Jackson, 1981; Kim \& Kang, 2010; Lee \& Lemyre, 2009; Lindell \& Hwang, 2008; Miceli, Sotgiu, \& Settanni, 2008; Siegel et al., 2003; Spittal et al., 2008). The discrepancy in the findings can be due to different measurements of preparedness, disaster types, research designs and geographical contexts. Importantly, to the best of our knowledge, none of the previous studies has empirically examined the underlying mechanisms through which education influences preparedness behaviors. In this study, we do not only investigate whether formal education plays a role in promoting preparedness actions, but also how, i.e. through which channels.

\section{(c) Education effects: Exploring the pathways}

Education can increase preparedness behavior through direct and indirect channels. Building upon previous studies on the returns to education, in particular for health and well-being (Brunello, Fort, Schneeweis, \& Winter-Ebmer, 2015; Gathmann, Jürges, \& Reinhold, 2014; Grossman, 2006), we draw the schematic diagram depicting different mechanisms (box i) as shown in Figure 1. In addition, Figure 1 also illustrates the relationship between preparedness and disaster experience (box ii), another key driver of preparedness actions.

Education, which in itself is influenced by different antecedent factors such as family background, genetic traits and abilities, can contribute to preparedness actions in direct and indirect manners. First, directly formal schooling is a primary way individuals acquire knowledge, skills, and competencies that can influence their preparatory efforts. There is established scientific evidence showing that cognitive activities during schooling such as solving mathematical problems can have long-lasting effects on neurological functioning (Eslinger et al., 2009; Quartz \& Sejnowski, 1997). As students move to higher grades, cognitive skills required in school become more progressively demanding and involve meta-cognitive skills such as categorization, logical deduction and knowledge transfers (Blair, Gamson, Thorne, \& Baker, 2005; Ceci, 1991; Nisbett, 2010). This abstract cognitive exercise alters the way educated individuals think, reason and solve problems (Baker et al., 2011). Indeed, experimental studies have shown that higherorder cognition improves risk assessment and decisionmaking skills (de Bruin, Parker, \& Fischhoff, 2007; Peters, Västfjäll, Slovic, Mertz, Mazzocco, \& Dickert, 2006). These are relevant components of reasoning related to risk perception and making choices about preparedness actions.

Furthermore, education can enhance the acquisition of knowledge, values and priorities as well as the capacity to plan for the future and to allocate resources efficiently (Cutler \& Lleras-Muney, 2010; Kenkel, 1991). Schooling can help individuals adopt preparatory measures by improving their knowledge of the relationship between preparedness and disaster risk reduction. Moreover, educated individuals may have better understanding of what preparedness measures to take. Recent evidence also shows that education may change time preferences such that more educated people are more patient and goal-oriented, and thus make more investments in their health and education for their future (Chew, Heckman, Yi, Zhang, \& Zhong, 2010; Oreopoulos \& Salvanes, 2011; PérezArce, 2011). Accordingly, this could influence adoption of such precautionary measures which require long term investments as purchasing disaster insurance.

In addition, indirectly the effect of education on preparedness behavior can be mediated by other factors including income, access to information and social capital. Needless to say, the prospect of receiving a higher income is one of the major returns to education (Card, 1999). The increased 
(i) (ii)

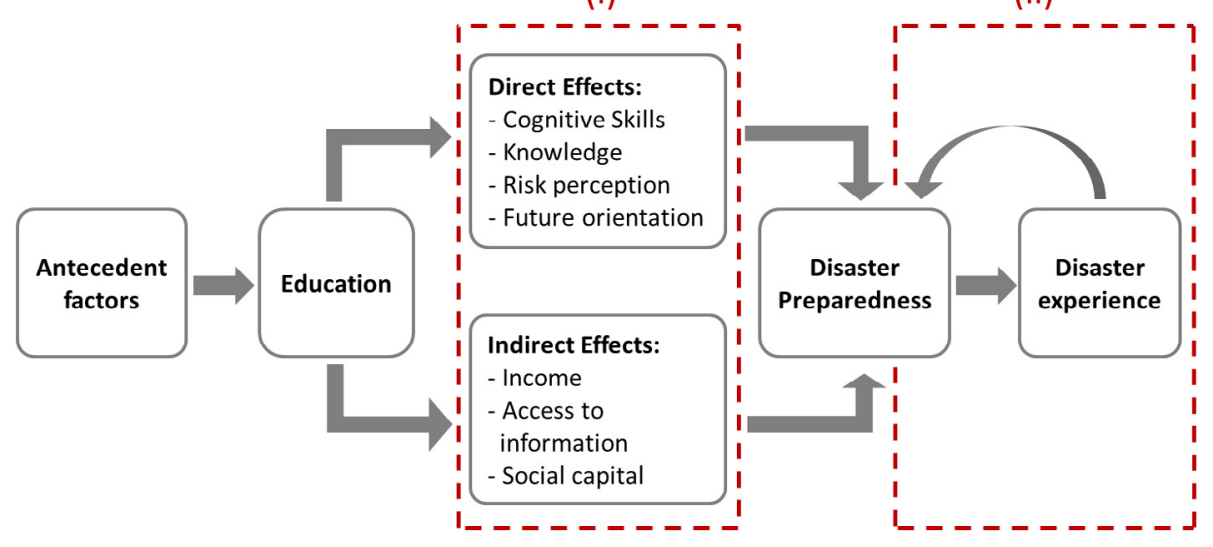

Figure 1. Flowchart explaining how education influences disaster preparedness and its interplay with disaster experience.

income afforded by high levels of education enables individuals to undertake costly preparatory measures such as purchasing disaster insurance or flood protection devices accordingly. Moreover, many empirical studies have shown that people with more years of formal education have access to more sources and types of information (Cotten \& Gupta, 2004; Neuenschwander, Abbott, \& Mobley, 2012; Wen, Rissel, Baur, Lee, \& Simpson, 2011). The more educated are found to be better informed and subsequently more likely to make use of new information such as on the danger of smoking or HIV/AIDS (de Walque, 2007, 2010). The level of education is not only highly correlated with access to weather forecasts and warnings but the highly educated are also able to better understand more complex environmental issues such as climate change (Rodriguez, Diaz, Santos, \& Aguirre, 2007; Xiao \& McCright, 2007). Subsequently, access to forecasts and early warnings allow individuals to respond and prepare for the hazards appropriately.

Another important channel through which education may increase preparedness activities is via social capital (broadly defined here as social networks, reciprocal ties and social participation), given that educated individuals are commonly found to have higher social capital (Huang, van den Brink, \& Groot, 2009; Lake \& Huckfeldt, 1998). The perception of risk and motivations to take preventive action can be transferred via social networks. Likewise, individuals who participate regularly in social activities can benefit from an exchange of useful information and warnings. Indeed, there is evidence that social participation, strong family and community networks and high level of trust are positively associated with preparedness behavior (Kirschenbaum, 2006; Solberg, Rossetto, \& Joffe, 2010; Witvorapong, Muttarak, \& Pothisiri, 2015).

\section{(d) Disaster experience and its interplay with education}

Besides education, prior disaster experience is another key factor determining preparedness behavior. Based on our conceptual framework shown in Figure 1, disaster preparedness is promoted through education and disaster experience. Education raises disaster preparedness which in turn reduces the likelihood of being affected by a disaster. Similarly, the households which have experienced loss and damages from disasters in the past learnt about their potential harmful impacts and consequently can become better prepared for future disaster events. Many studies have shown that people who have expe- rienced floods (Bubeck, Botzen, Kreibich, \& Aerts, 2013; Lawrence, Quade, \& Becker, 2014; Lindell \& Hwang, 2008; Siegrist \& Gutscher, 2008), earthquakes (Mileti, Fitzpatrick, \& Farhar, 1992; Tekeli-Yeşil, Dedeoğlu, Tanner, BraunFahrlaender, \& Obrist, 2010), hurricanes (Horney, Snider, Malone, Gammons, \& Ramsey, 2008; Sattler et al., 2000) and wildfires (McGee \& Russell, 2003) are more likely to prepare for a future event.

Theoretically, previous disaster experience may influence preparedness behavior through channels similar to education. Hazard awareness and risk perception, for example, are closely related to prior disaster experience. Having been affected by and surviving a disaster may increase awareness about the potential for destruction, demonstrate benefits of preparation and evacuation, and enhance knowledge on how to recover in its aftermath as well as how to cope with subsequent disaster threats (Sattler et al., 2000). This in turn increases preparedness behavior likewise.

While disaster experience appears to be a key driver of disaster preparedness behavior, certainly it is not an ideal way to promote household/individual adoption of precautionary measures. The fundamental question hence is how to increase risk awareness for people who have not been affected by disasters so far. Here we argue that education can substitute disaster experience such that highly educated individuals can understand the disaster risks and anticipate the impacts without first-hand experience. If this argument holds, we expect to find an interplay between disaster experience and education in shaping preparedness behavior.

\section{RESEARCH DESIGN AND METHODS}

\section{(a) Study areas: The Philippines and Thailand}

\section{(i) Survey designs}

Data from two Southeast Asian Countries, the Philippines (PH) and Thailand (TH), are employed for the analysis (Figure 2). With diverse socio-economic backgrounds of the populations and different exposure to disaster risk, the two countries represent well-suited cases for this study. The survey data used in both countries were collected by the authors which allowed us to tailor the research instruments to our research questions and to reach a high degree of comparability between the cases. 

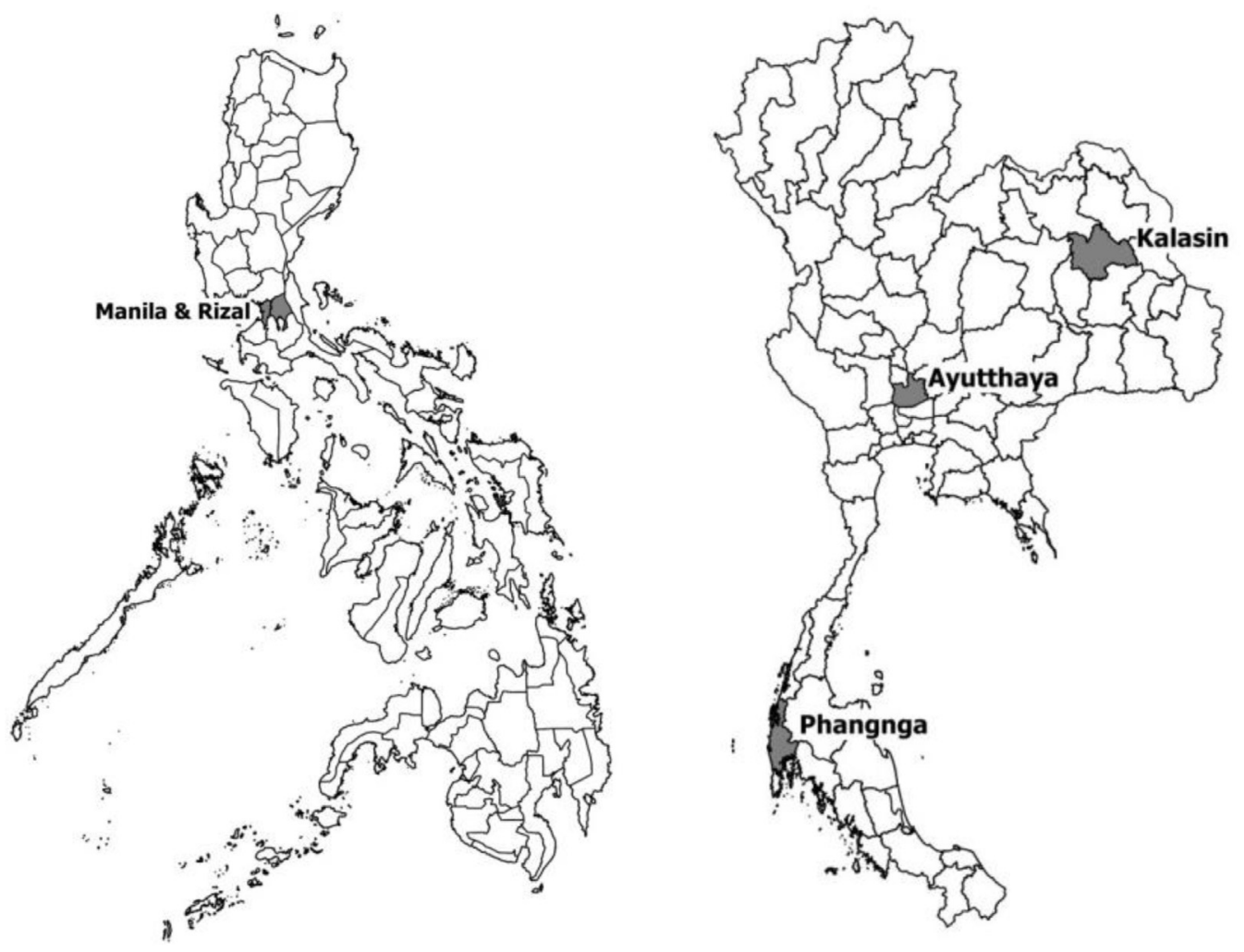

Figure 2. Map of study areas in the Philippines and Thailand.

The data for the Philippines were collected in Masinag, Batasan, and Montalban, three low-income districts in Metro Manila and the nearby province of Rizal with a rural, periurban population. The data collection was part of a research project on health vulnerabilities in impoverished neighborhoods and the role of community-based health programs in improving the living condition of poor households. Interviews were conducted with female members of a social development organization, the Kasagana-Ka Development Center Inc. (KDCI), which offers various health services to its members as part of a community health program. In most cases, the respondents were female household heads. A two-stage cluster sampling was employed: First, a sample of neighborhoods was randomly selected as primary sampling units. The target population consisted of people who lived in neighborhoods where our partner organization was active and who did not have access to the health program at the time of the survey. In the second step, respondents were randomly drawn from the group of KDCI members in the selected neighborhoods.

The data were collected using face-to-face interviews in February 2014. In total, 889 respondents (aged 20-75 years) were interviewed using standardized questionnaires. Although the data are based on a probability sampling approach, its generalizability is restricted to the members of our partner organization who lived in the neighborhoods which fulfilled the specified criteria. Still, we believe that the sample selected for this study is meaningful and represents an interesting case which is informative to test our central hypotheses. The three study areas in the Philippines have been frequently affected by natural calamities in the past with devastating consequences for the local communities. Primarily, these areas are exposed to risks of floods, landslides and storm damages caused by the numerous typhoons that hit the country with an average of 20 tropical storms per year (Brower, Magno, \& Dilling,
2014). Furthermore, all three areas have a significant earthquake hazard as they are located at close range of the Marikina Valley Fault System.

The Thai data were obtained from a representative household survey of three provinces, namely, Phang Nga, Kalasin, and Ayutthaya. The survey purposively selected the three provinces with different hazard exposure in order to investigate household responses to climate change and natural disasters. The province of Phang Nga, located along the Indian Ocean coastline, was strongly affected by the 2004 Asian Tsunami with 4,224 deaths, accounting for $78 \%$ of the death toll from the 2004 tsunami in the country. The interior province of Ayutthaya is situated on the low-lying area in the central plains and is exposed to frequent flooding. Kalasin is located in the northeast and is particularly prone to drought but floods and windstorms are also not uncommon. The survey was conducted based on a stratified two-stage sampling design with villages and housing blocks as primary sampling units. In stage two, a random sample of $25 \%$ of districts in the selected provinces, $25 \%$ of villages in the selected districts and $25 \%$ of households in the selected villages was drawn for interview. Interviews were conducted face-to-face with one male or female member aged 15 or above from each household. The survey was carried out between May-August 2013 with 1,310 respondents participating in the study. Further information about the survey can be found in Basten, Muttarak, and Pothisiri (2014).

\section{(ii) Education systems in the Philippines and Thailand}

The schooling systems in the Philippines and in Thailand share some similarities. In Thailand, formal education consists of at least 12 years of basic education which is divided into six years of elementary and six years of secondary education. Students typically enter elementary school at the age of six. In the past decades, there were major reforms in the schooling system 
such as changes in the national curricula and compulsory school age, which was extended to 15 years of age (Chankrajang \& Muttarak, 2017). In the Philippines, the last major schooling reform took place in 2011, when the number of years of basic education was raised from 10 to 13 years (or from 6 to 13 years of compulsory schooling). Prior to that, basic education consisted of six years of elementary school starting at the age of six and four years of high school education. While the educational expansion led to a sharp increase in the primary school net enrollment rates from $76 \%$ to $92 \%$ during 1973-2014 in Thailand, the rates fluctuated around a high average of $90 \%$ in the Philippines, where early school reforms led to improved access to basic education for large parts of the population.

In the Philippines, disaster preparedness lessons and trainings were only recently integrated into primary and high school curricula. Educational institutions were mandated by the country's Disaster Risk Management Act of 2010 to hold regular flood, typhoon, and earthquake drills (Republic of the Philippines, 2011). Despite this, many schools have not yet started to fully implement disaster preparedness modules in their educational program. In Thailand, to our knowledge, disaster education has not yet been incorporated into the formal school curriculum. While disaster education programs may increase disaster risk awareness and knowledge and consequently preparedness actions, there is limited empirical evidence supporting the effectiveness of such initiatives (Barakat, Bengtsson, Muttarak, \& Kebede, 2016).

\section{(b) Measurement}

The paper aims to explore the role of education, disaster experience and a set of potential mediating factors in explaining a person's tendency to undertake preparedness measures. The variables used in the analysis and their measurement are described below.

\section{(i) Dependent variables}

Disaster preparedness is measured in two steps. The first outcome is a binary variable coded one if the household has taken any preparedness measures against disasters and zero otherwise. If so, secondly, the respondents were asked to identify all precautionary measures that were undertaken. The answers are categorized into five categories (none, one, two, three, four, and five or more preparedness measures). The resulting ordinal variable - the number of preparedness measures taken - allows us to consider not only whether a household was prepared at the time of the surveys, but also to what extent.

\section{(ii) Explanatory variables}

Education is measured as years of schooling up to tertiary education (college, university, vocational training, etc.) in the Philippines. In Thailand, detailed categories of the respondents' highest level of education are used to construct the variable year of schooling. Note that this variable is based on a quantifiable notion of formal education and does not consider softer aspects of education e.g., informal education which may as well play a key role.

Disaster experience is measured as a dummy variable which takes the value one if the household has been affected by a natural disaster in the past three years. Those who experienced housing damages, damages to livelihoods and/or injuries or loss of household members are defined as being affected by a disaster. We chose to confine disaster experience to people who directly experienced loss and damages because preparedness behavior is largely determined by the severity of exposure (Norris et al., 1999). In our measurement of disaster experi- ence, three years were chosen as a reference period to minimize recall biases. Also, since it has been shown that the duration of people's memory of specific disaster events is limited (Kirkby, 1974), we expect disasters that occurred in the near past to be more influential for household decision making.

We also experimented with other measures capturing disaster affectedness such as the total number of disasters experienced, the number of injured or killed household members and the total damage encountered. We found that the binary variable whether a household experienced a disaster had the strongest predictive power in our models compared to other measures, which are strongly influenced by outliers (i.e. few households experienced many major disaster events). Therefore, in our analysis, we focus on the binary measure which captures both damage to material values and personal losses.

\section{(iii) Mediating factors}

Household income per capita, measured in local currency and divided by 1,000 serves as an indicator of economic resources. Cognitive skills are measured using a word recall test where respondents were read a list of 10 simple nouns and asked to promptly repeat as many of those words as possible in any order. Although word recall is designed to estimate episodic memory abilities, it has been shown to be strongly correlated with cognitive abilities (Oberauer, Süß, Schulze, Wilhelm, \& Wittmann, 2000).

In the Philippines, we additionally test for future orientation (time preference) based on a hypothetical choice set. Respondents were asked a series of questions in which they had to choose between receiving a fix amount of 10,000PHP $(\sim 220 \$)$ in one year or a gradually decreasing amount immediately (Benzion, Rapoport, \& Yagil, 1989; Shelley, 1993). A person's future orientation is approximated based on his/her willingness to wait for the larger amount. Taking preparedness actions involve immediate costs and delayed benefits. People with future-oriented time preferences thus should be more likely to adopt preparedness measures since they value future outcomes more than immediate ones. In addition, we measure risk preference using a self-assessment test of a person's general willingness to take risks (Dohmen, Falk, Huffman, Sunde, Schupp, \& Wagner, 2011). Attitudes toward risk can potentially be related to adoption of preventive measures such as purchasing of disaster insurance to insure against catastrophic events.

In Thailand, we assess disaster risk perception by asking the respondents to estimate the possibility of major disasters in their community in the next five years given the choices: very unlikely, somewhat unlikely, somewhat likely and very likely. Moreover, the respondents were also asked about climate change perception i.e. how they perceive the impact of climate change on their family (very weak, weak, moderate, strong and very strong).

Finally, we consider the role of social capital in both countries. Note that the measurement of social capital differs in the two countries due to different questions used in the surveys. Social capital is measured as access to help in the neighborhood in the Philippines and voluntary participation in community activities in Thailand. The former denotes social support available while the latter represents civic engagement and social participation. Although the measurements in the two countries capture different dimensions of social capital, broadly speaking they both depict the strength of embeddedness within the social networks in the community (Coleman, 1988). While it is not possible to directly compare the level of social capital between the two countries, we assume that individuals with greater social support and who are more engaged in community activities also have better access to information, expertise and material resources through their 
social networks. These are assets which in turn are useful in preparations against disasters (Witvorapong et al., 2015).

The summary statistics of all variables used in the analysis including additional information on their measurement are presented in Table 5 in the Appendix.

\section{(iv) Control variables}

Furthermore, a set of additional variables that have been shown to be relevant in the literature are accounted for. We control for socio-demographic and household characteristics including age, sex (Thailand only), years of residence in the neighborhood (the Philippines only) or in the household (Thailand only), marital status, employment status, self-rated health, household size, proportion of preschool children aged $\leq 5$ and proportion of older persons aged $\geq 65$ in the household and proportion of household members with at least secondary education. To account for geographical characteristics potentially related to exposure to natural hazards, we control for community dummies and information about whether the household is located near a river $(<200 \mathrm{~m})$, near the sea $(<1 \mathrm{~km})$ or near a mountain $(<200 \mathrm{~m})$.

In the Philippines, there is additional information on early work experience (before age 12) as a proxy for family wealth in childhood. Parental education background is measured with two dummy variables that indicate whether the mother and/or the father have obtained some secondary education. In addition, dummies that take the value one if the mother or father died early or was unknown to the child are added. In Thailand, controls for whether the household owns the house and land where the family lives are also included.

\section{(c) Estimation strategy}

Two different outcome measures: (1) being prepared (binary); and (2) number of preparedness measures undertaken (ordinal) are used in the statistical analysis. The probability of taking preparedness actions (a binary outcome) is estimated using logit models while the ordinal outcome is analyzed using ordered logit estimation. All standard errors are clustered at the neighborhood (the Philippines, $m=72$ ) and village level (Thailand, $m=35$ ). We check for the robustness of our results using different functional specification (poisson and tobit for the non-categorized, continuous outcome) and estimation procedures (multilevel modeling). All reported results are robust to the use of different procedures, lending support to the reliability of our findings.

For the empirical analysis, first, we estimate a baseline model with education $E$, disaster experience $X$, and a set of control variables $C$ on the right-hand side of the equation to test for the effects of education and experience on disaster preparedness. The baseline model is then gradually extended by including a set of mediating variables $Z$ that have been identified as potentially relevant to disaster preparedness in the literature. Each mediating variable is expected to: (1) have an effect on preparedness levels; and (2) explain part of the education effects. In general form, the baseline and extended models can be written as follows:

$Y=f(E, X, C)$

$Y=f(E, X, Z, C)$

The estimation procedure allows us to: (1) investigate the association between education and disaster preparedness; and (2) test whether and to what degree the relationship between education and disaster preparedness is explained by the mediating factors $Z$.
Following the principles of path analysis, the effect of education on disaster preparedness is decomposed into two parts: (1) an indirect effect (the part mediated by $Z$ ); and (2) a direct effect (the part unmediated by $Z$ ). Unlike in linear models, decomposing direct and indirect education effects, which are mediated through another factor, is not straightforward in models with a non-linear functional form such as logit or ordered logit. In these models, gradual inclusion of additional mediating factors leads to rescaling due to variation in the included variables. This makes a direct comparison of the effects between the baseline and extended model as in linear estimation impossible. Here we employ the KHB method developed by Karlson, Holm, and Breen (2012) which offers a way to handle rescaling problems and to consistently compare coefficients of non-linear nested models.

The KHB method follows a two-step procedure. First, the mediating factor $Z$ is regressed on the original explanatory variable $E$, i.e. years of education in our case. From this estimation the residual $R$ is derived. $R$ captures the share in variation in the mediator that is not related to the explanatory variable, but caused by another factor. In the second step, the residual is included in the reduced baseline model in which the outcome is regressed on the explanatory variable not controlling for the mediator. The inclusion of the residual does not change the coefficient of the explanatory variable as $R$ is, by construction, unrelated to $E$ (only marginal changes may occur). However, by including $R$ in the model, we capture both the variation in $Z$ that is explained by $E$ (contained in the coefficient of $E$ ) and the variation unexplained by $E$ (contained in the coefficient of $R$ ). The underlying functional scale of the model, which would have changed if we had simply extended the reduced model by $Z$, is thus harmonized between the baseline and extended model making a direct comparison of the effects possible. The KHB method further tests if the occurring difference in effect sizes between the baseline and extended models is significantly different from zero i.e. if the mediating factor significantly explains part of the education effects.

\section{RESULTS}

\section{(a) Descriptive results}

Figure 3 displays the distribution of preparedness actions taken by type of measure and country. These elicit important differences between the two countries. Overall, disaster preparedness is higher in the Philippine sample: $76 \%$ reported undertaking disaster preparedness actions as compared to only $32 \%$ in Thailand. Similar to overall disaster preparedness, the Philippine sample shows a higher degree of activities carried out for most preparedness measures, except for setting up of a family evacuation plan. For example, more than $50 \%$ of the respondents in the Philippines reported having stockpiled food at home in order to be self-reliant in case a disaster strikes as compared to only $14.4 \%$ in Thailand. It is also noticeable that while food storage, emergency kit preparation, structural upgrades and setting of a family emergency plan are common in both countries, very few respondents - $6.3 \%$ in the Philippines and $1.4 \%$ in Thailand - reported to have a disaster insurance.

\section{(b) Results from baseline models}

Table 1 reports the results of the baseline specification from the logit and ordered logit models for the Philippines and Thailand with coefficients presented in odds ratios. 


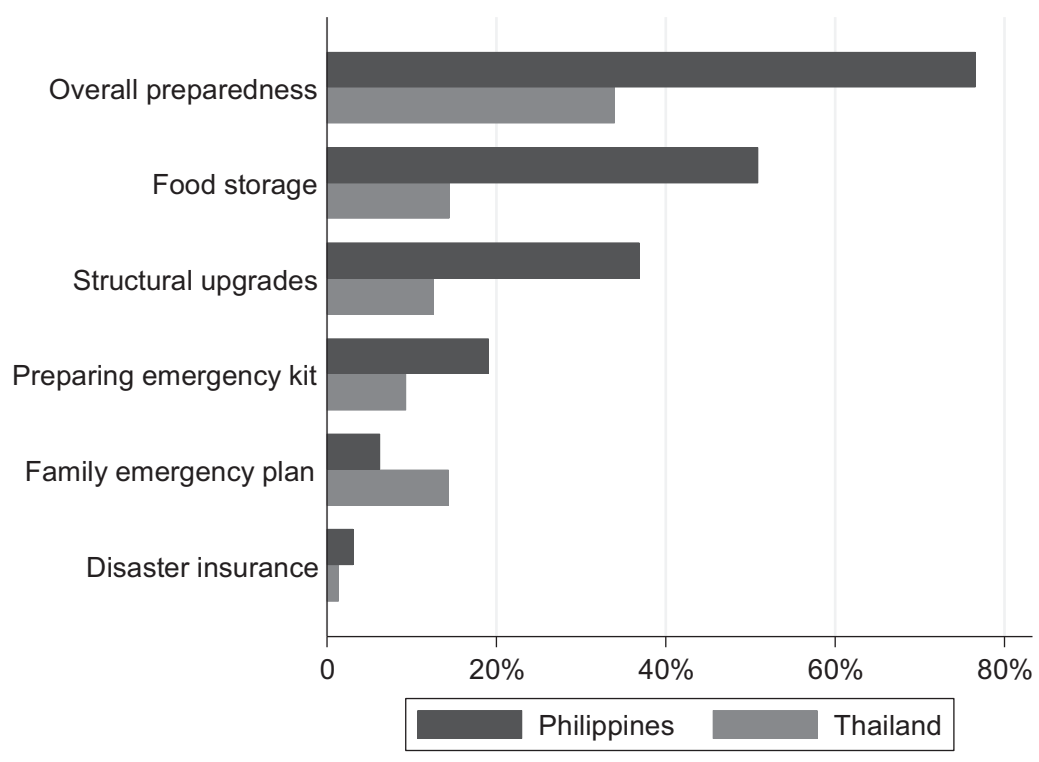

Figure 3. Disaster preparedness measures by country.

Table 1. Baseline specification: logit and ordered logit models of disaster preparedness

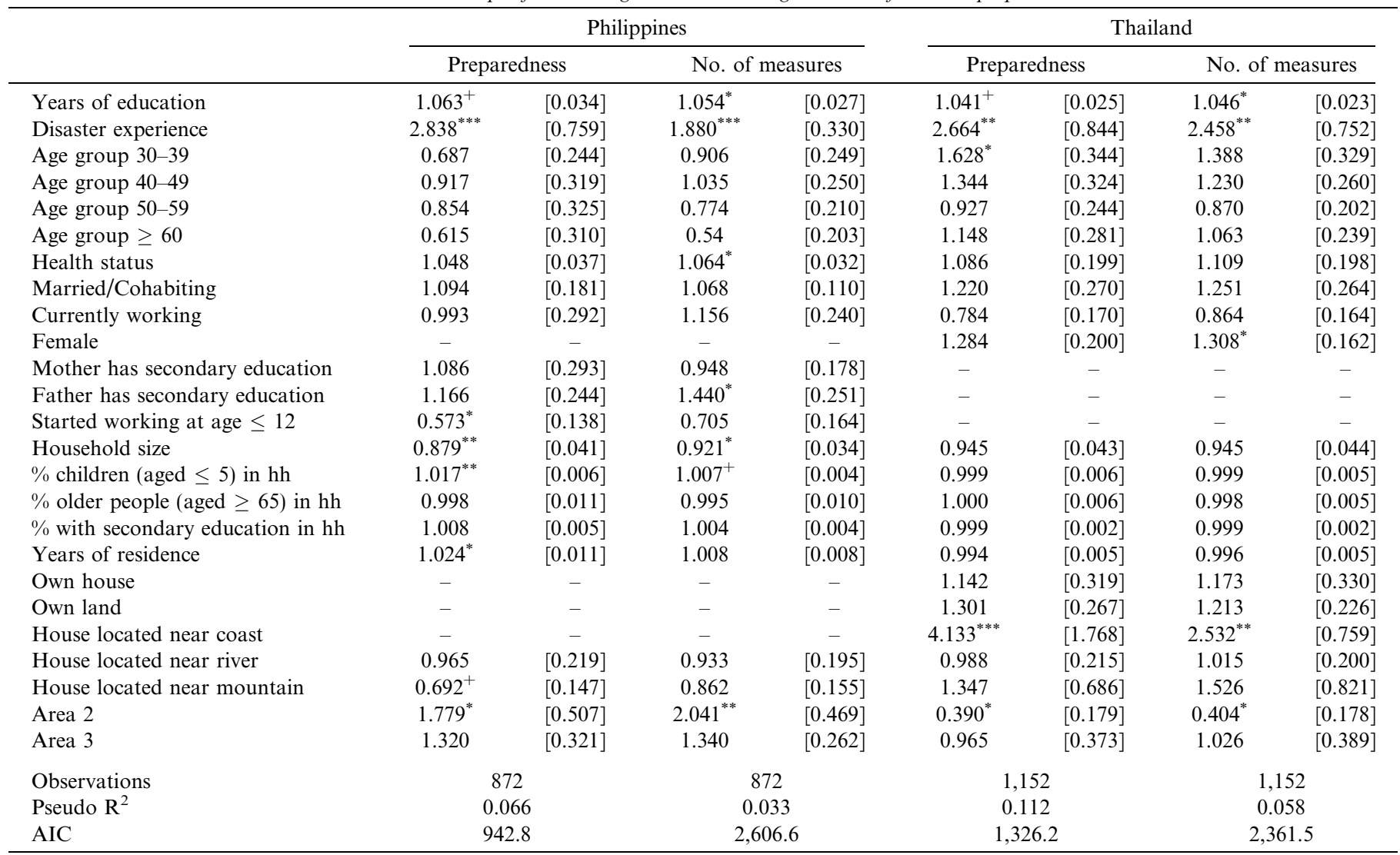

${ }^{+} p<0.1,{ }^{*} p<0.05,{ }^{* *} p<0.01,{ }^{* * *} p<0.001$.

Notes: Cell entries are odds ratios with robust standard errors in parentheses. Standard errors are clustered at the neighborhood level (PH) or village level (TH). Dummy variables of whether mother and/or father are unknown (PH) are not displayed.

In line with the previous studies, we find that education and disaster experience positively influence the propensity to undertake precautionary actions in both countries and for both outcome measures. According to the logit models, an additional year of schooling raises the odds of undertaking preparedness measures by $6.3 \%$ in the Philippines and by $4.1 \%$ in Thailand. Likewise, disaster experience exhibits a strongly significant effect on disaster preparedness in all esti- 
mations. Based on the logit models, having been affected by a disaster in the past 3 years raises the odds of being prepared 2.8 and 2.7 times in the Philippines and Thailand, respectively. Similarly, the effects of disaster experience are mirrored in the ordered logit regressions.

Apart from education and disaster experience as main explanatory variables, other factors also influence the preparedness level. In the Philippines, households with greater share of children are more likely to undertake preparedness measures. An increase of $10 \%$ in the proportion of household members aged $\leq 5$ leads to an increase in the odds of preparedness by $17 \%$ in the logit and $7 \%$ in the ordered logit models. Households with a larger number of household members, on the other hand, have a smaller probability of taking preparedness actions, which might reflect wealth or social background effects. Furthermore, based on the ordered logit estimation, we find weak evidence in the Philippines that father's education level has a positive effect on respondent's tendency to be prepared. Moreover, respondents who started working at early age, those who have only recently moved to a neighborhood, and those with poor health express a lower level of disaster preparedness. The first two effects are only statistically significant in the logit models while the latter effect is only significant in the ordered logit model. Disaster preparedness also varies considerably with geographical locations. The respondents from Montalban, the peri-urban area at the outskirts of Metro Manila, are significantly more likely to undertake preparedness measures than the respondents from Batasan, a neighborhood rarely affected by natural disasters.

In Thailand, among the control variables, the geographical location seems to matter most. Living close range to the shoreline $(<1 \mathrm{~km})$ is positively related with disaster preparedness. At the same time, the respondents from Kalasin, one of the internal regions, express a significantly lower degree of preparedness as compared to the respondents from Phang Nga, the region most strongly affected by the 2004 Tsunami. Besides, there is some evidence for a gender effect in the ordered logistic regressions, with women being more likely to carry out higher number of preparedness measures than men.

\section{(c) Decomposing education effects}

Both in the Philippines and Thailand, we find that education positively influences whether people undertake preparedness actions. In this section, we empirically test for different direct and indirect underlying mechanisms that might explain the observed relationships. First, the effects of potentially relevant mediating factors on disaster preparedness are estimated using the standard logit and ordered logit specification. In a second step, we consider changes in education effects between the reduced baseline and extended models to determine the explanatory power of the mediators using the KHB method designed for non-linear nested models.

In Table 2, the baseline model is gradually extended by various potentially relevant mediators: household income, cognitive ability, future orientation, risk attitude, and social capital in the Philippines; and household income, cognitive ability, risk perception, felt impact of climate change and social capital in Thailand. For brevity, only the findings from the ordered logit estimation are reported in Table 2. The estimates for the control variables are not included and the full models are presented in the Appendix (Tables 6 and 7). The logit model results, which widely confirm the ordered logit findings, are available upon request.
Household income per capita and word recall are included in the models as first potential mediating factors. Both for the Philippine and Thai data, neither income nor word recall exhibits a significant effect on disaster preparedness. Furthermore, future orientation, included in model 3 for the Philippines does not show a significant effect on disaster preparedness either.

In the subsequent models, variables that measure concepts related to risk attitudes and perception are considered. While risk attitudes in the Philippines do not explain differences in preparedness behavior, we find a strongly significant positive effect of risk perception in Thailand. Compared to the reference group who perceives disaster risks to be very low, the respondents who perceive a moderate or high disaster risk are 2.4 and 2.6 times more likely to undertake preparedness measures, respectively. Similarly, perceiving that climate change has substantial impact on the family increases the odds of being in the group undertaking most preparedness measures by 1.8 times.

Next, variables that capture dimensions of social capital (measured as social support in the Philippines and social participation in Thailand) are included. Having higher social capital leads to a significant $86.5 \%$ and $107.8 \%$ increase in the odds of taking preparedness actions in the Philippines and Thailand, respectively. Indeed, besides the perception of disaster risks, social capital is a strong determinant of disaster preparedness in both countries.

In a final step, a full set of mediating variables is controlled for. The reported effects of all mediators remain robust in the full models. Across all models, education coefficients remain significant although for the Thai data, the size of education coefficients decreases when some of the mediators are included. In the Philippines, on the other hand, the education effects remain relatively stable. The differences in the effect sizes form the basis of the KHB analysis, which is presented in Table 3.

Table 3 presents the results from the KHB models where the effects of education on disaster preparedness are disentangled. The first two rows report the total and direct effects of education for the reduced model without and the extended model with the considered mediating factor, respectively. The last row reporting indirect effects shows the difference between the coefficient in the reduced and extended model. Note that the estimates slightly differ between the standard ordered logit models and the KHB estimation. The delta method applied in the KHB procedure tests if the change in coefficients is significantly different from zero i.e. whether the mediating factor confounds education.

In the Philippines, the inclusion of additional factors does not lead to a significant change in the education coefficients. None of the considered theoretically relevant mediators can explain the reported education effects. In Thailand, on the other hand, three of our mediators explain part of the reported education effects. Based on the KHB estimates, disaster risk perception explains $11.1 \%$, perception of the impacts of climate change explains $11.0 \%$ and the social capital indicator explains $23.3 \%$ of the previously found education effects on disaster preparedness.

\section{(d) Interplay between education and experience}

Both education and disaster experience can trigger learning processes that lead to increased preparedness levels. If this argument holds, the effects of both variables are expected to depend on each other. We test for the interplay between the two variables in a model which includes an interaction term 
Table 2. Extended ordered logit models: Exploring the impacts of mediators on disaster preparedness

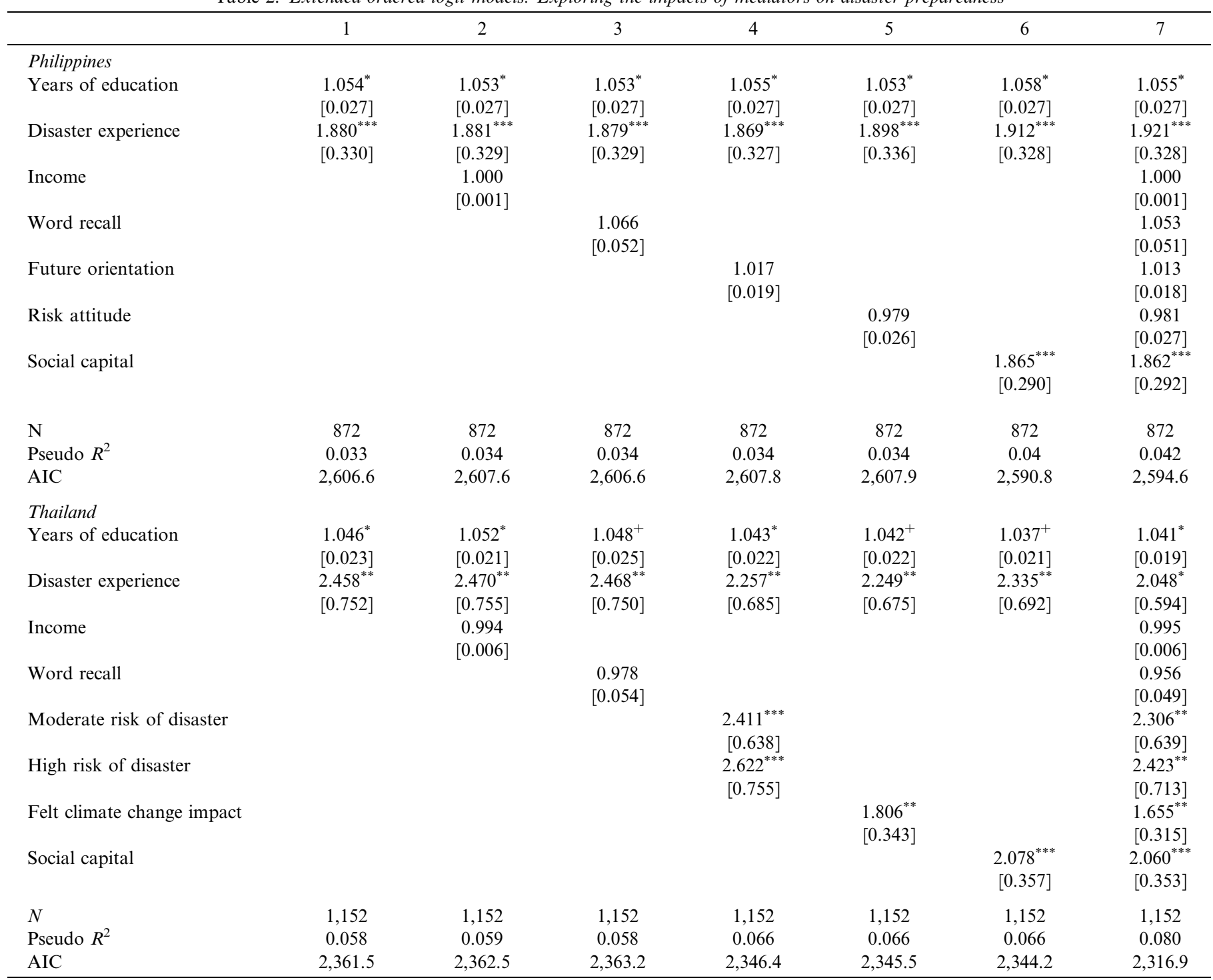

${ }^{+} p<0.1,{ }^{*} p<0.05,{ }^{* *} p<0.01,{ }^{* * *} p<0.001$.

Notes: Cell entries are odds ratios with robust standard errors in parentheses. Standard errors are clustered at the neighborhood level (PH) or village level (TH). All control variables included in the models, but not displayed.

of education (continuous) and previous disaster experience (binary). Table 4 presents the results from the logit and ordered logit models investigating the interplay between education and disaster experience. Here only the coefficients of the main variables of interest are displayed (Full results are shown in the Appendix in Table 8).

Interestingly, when the interaction term between education and experience is included in the model, both the main effects of education and experience increase. The interaction term itself is negative and statistically significant revealing an important interplay between the two factors. Similar to the results in Table 1 , respondents with prior disaster experience have higher levels of disaster preparedness. For education, however, we find that the effect differs significantly by disaster experience. The significant and negative interaction term implies that education has a positive influence on disaster preparedness only for those who have not yet experienced a disaster in the past. For the group with disaster experience, on the other hand, we find that the education effect almost cancels out suggesting that disaster affectedness boosts preparedness for the more and less educated to a similar level. The interplay between the two variables is illustrated for both countries in the plot of marginal effects in Figure 4.

Note that controlling for relevant demographic and socioeconomic factors, the average preparedness level in the Philippines remains about $40 \%$ higher than in Thailand. Despite these differences in preparedness levels, we can observe the same systematic pattern with respect to the interplay between education and experience on disaster preparedness. Education significantly raises preparedness actions for those who have not been affected by a disaster in both countries. For the group with disaster experience, however, there seems to be no particular relationship between education and preparedness behavior as depicted by a flat line in both countries. Interestingly, education seems to allow the non-affected individuals to reach a preparedness level almost as high as their counterparts with previous disaster experience. Indeed, this suggests that education can be an effective mean to 
Table 3. KHB models: Decomposing education effects on disaster preparedness (based on ordinal outcome: number of preparedness measures taken)

\begin{tabular}{|c|c|c|c|c|c|}
\hline & Income & Word recall & Future orientation & Risk attitude & Social capital \\
\hline \multicolumn{6}{|l|}{ Philippines } \\
\hline \multirow[t]{2}{*}{ Total effect } & $1.054^{*}$ & $1.055^{*}$ & $1.054^{*}$ & $1.054^{*}$ & $1.052^{*}$ \\
\hline & {$[0.027]$} & {$[0.026]$} & {$[0.027]$} & {$[0.027]$} & {$[0.027]$} \\
\hline \multirow[t]{2}{*}{ Direct effect } & $1.053^{*}$ & $1.053^{*}$ & $1.055^{*}$ & $1.053^{*}$ & $1.058^{*}$ \\
\hline & {$[0.027]$} & {$[0.027]$} & {$[0.027]$} & {$[0.027]$} & {$[0.027]$} \\
\hline \multirow[t]{2}{*}{ Indirect effect } & 1.001 & 1.002 & 0.999 & 1.001 & 0.995 \\
\hline & {$[0.001]$} & {$[0.002]$} & {$[0.001]$} & {$[0.001]$} & {$[0.004]$} \\
\hline Effect change in $\%$ & $1.86 \%$ & $3.21 \%$ & $-1.30 \%$ & $1.58 \%$ & $-9.89 \%$ \\
\hline \multirow[t]{2}{*}{$N$} & 872 & 872 & 872 & 872 & 872 \\
\hline & Income & Word recall & Disaster risk perception & Felt climate change impact & Social capital \\
\hline \multicolumn{6}{|l|}{ Thailand } \\
\hline \multirow[t]{2}{*}{ Total effect } & $1.046^{*}$ & $1.046^{*}$ & $1.048^{*}$ & $1.047^{*}$ & $1.048^{*}$ \\
\hline & {$[0.023]$} & {$[0.023]$} & {$[0.023]$} & {$[0.023]$} & {$[0.023]$} \\
\hline \multirow[t]{2}{*}{ Direct effect } & $1.052^{*}$ & $1.048^{+}$ & $1.043^{*}$ & $1.042^{+}$ & $1.037^{+}$ \\
\hline & {$[0.021]$} & {$[0.025]$} & {$[0.022]$} & {$[0.022]$} & {$[0.021]$} \\
\hline \multirow[t]{2}{*}{ Indirect effect } & 0.994 & 0.998 & $1.005^{+}$ & $1.005^{+}$ & $1.011^{* *}$ \\
\hline & {$[0.006]$} & {$[0.006]$} & {$[0.003]$} & {$[0.003]$} & {$[0.004]$} \\
\hline Effect change in $\%$ & $-13.65 \%$ & $-5.32 \%$ & $11.13 \%$ & $10.96 \%$ & $23.28 \%$ \\
\hline$N$ & 1,152 & 1,152 & 1,152 & 1,152 & 1,152 \\
\hline
\end{tabular}

${ }^{+} p<0.1, \stackrel{*}{p}<0.05,{ }^{* *} p<0.01,{ }^{* * *} p<0.001$.

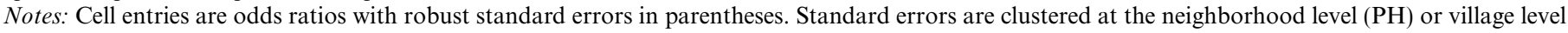

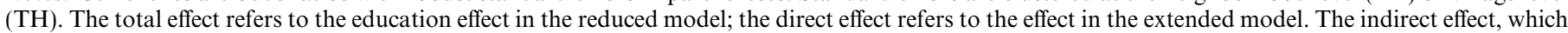

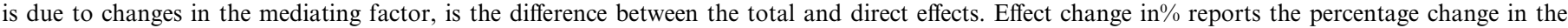

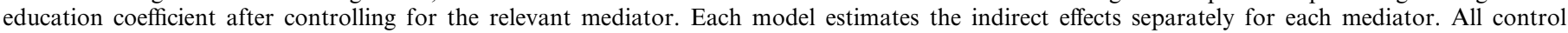
variables are included in the models, but not displayed.

Table 4. Exploring the interplay between education and disaster experience

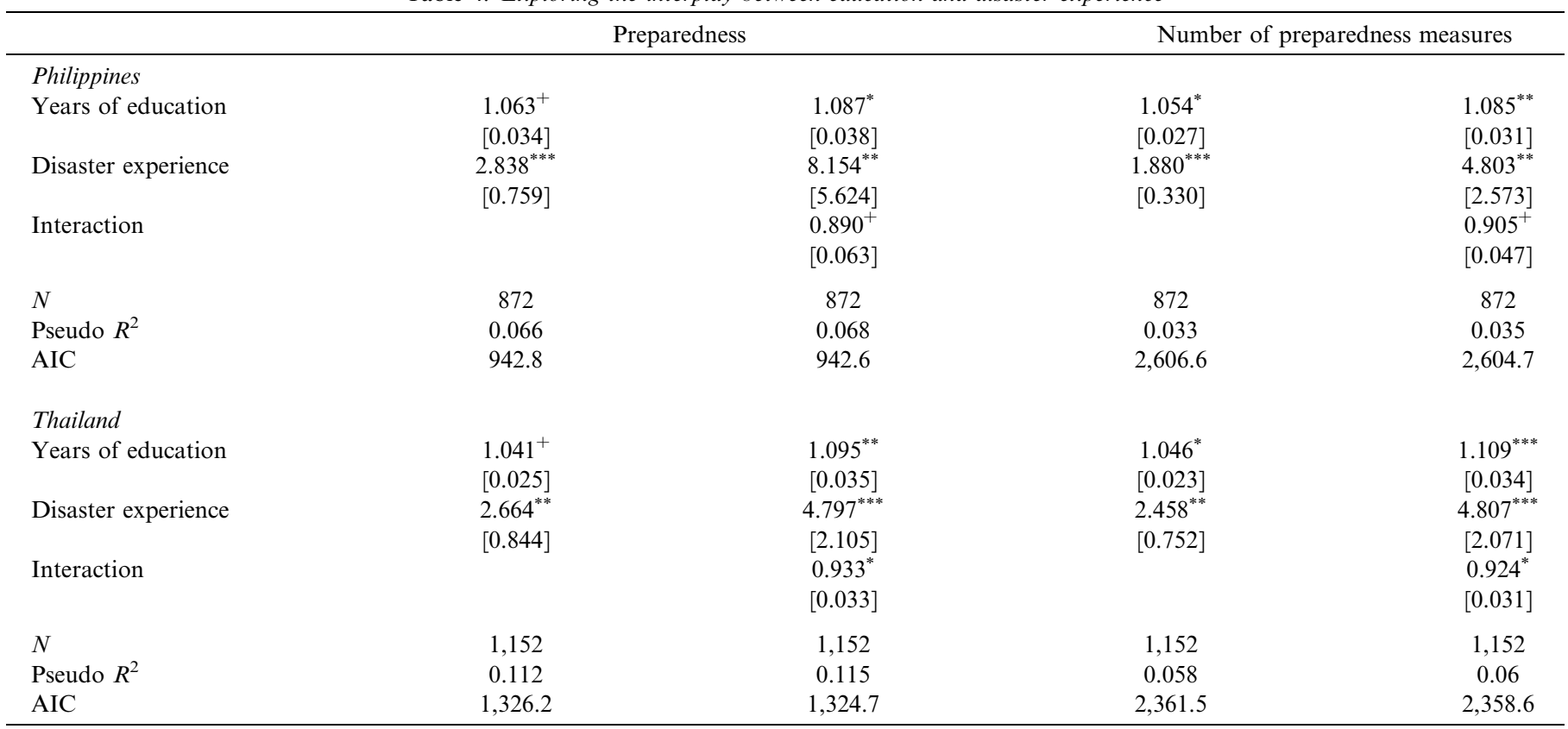

${ }^{+} p<0.1,{ }^{*} p<0.05,{ }^{* *} p<0.01,{ }^{* * *} p<0.001$.

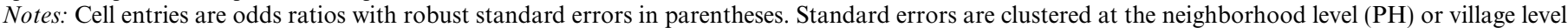

(TH). All control variables are included in the models, but not displayed.

supplement disaster experience in raising preparedness actions. Once being affected by a disaster, both the highly educated and less educated alike achieve a similar level of disaster preparedness.

\section{DISCUSSION AND CONCLUSION}

Analyzing original survey data from the Philippines and Thailand, we have shown that education promotes prepared- 
Philippines: Marginal effects with $95 \% \mathrm{Cls}$

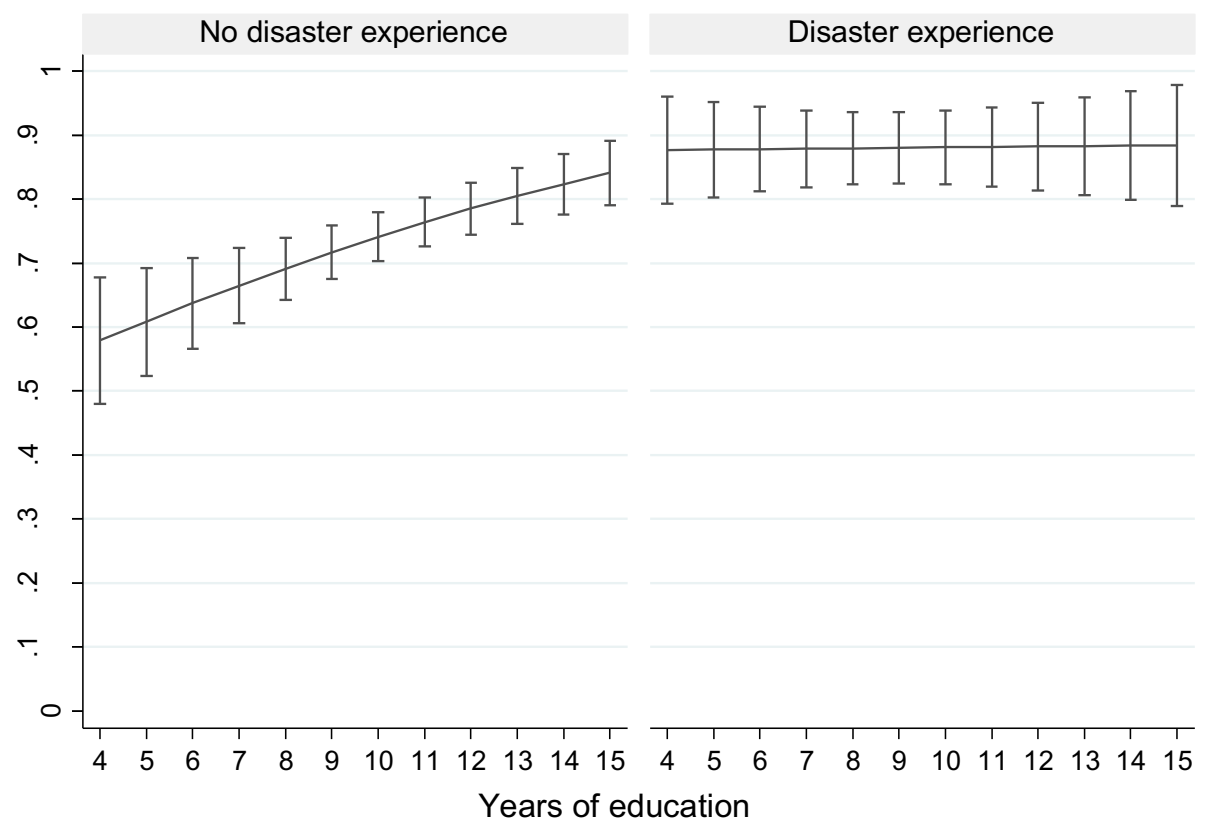

Thailand: Marginal effects with $95 \% \mathrm{Cls}$

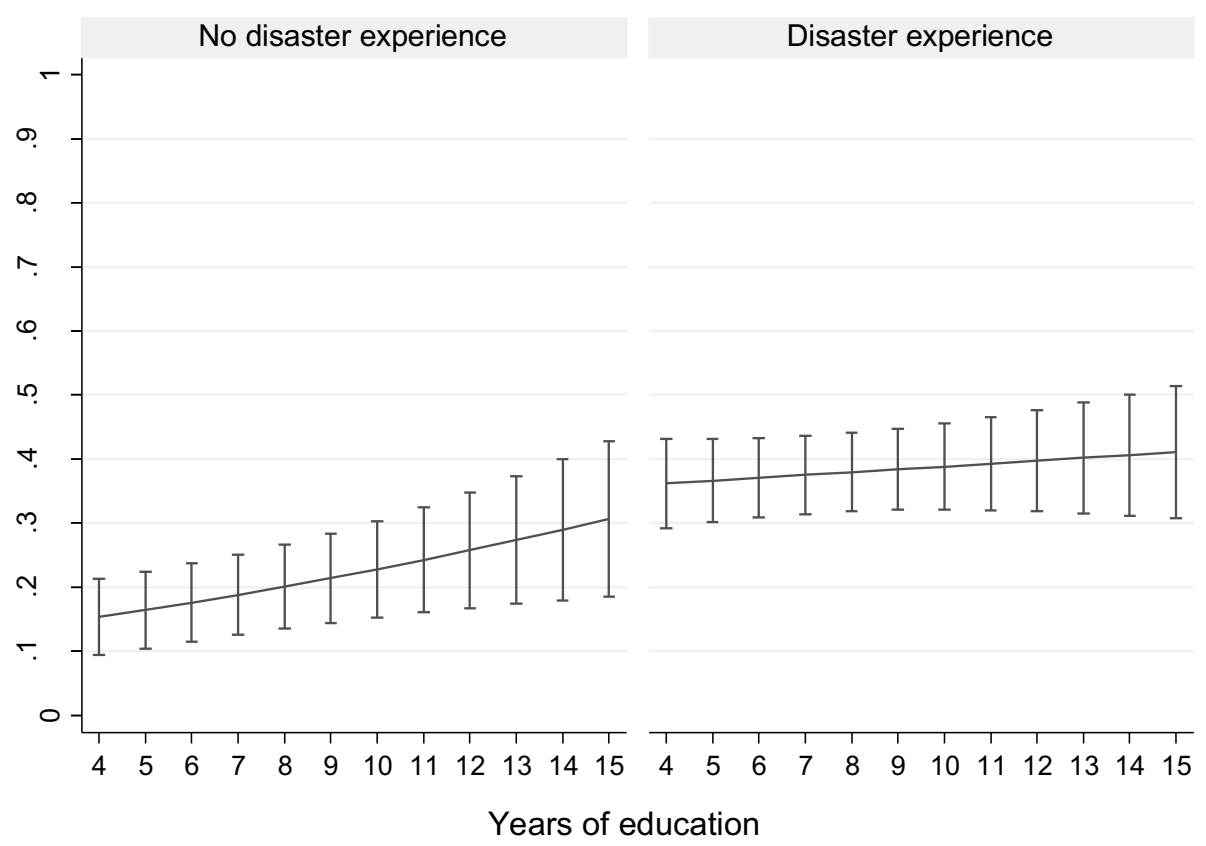

Figure 4. Plots of marginal effects from logit models displaying the probability of taking preparedness measure by years of education in the Philippines and Thailand.

ness behavior particularly for people who have not been affected by a disaster in the recent past. The results are consistent for both countries and for different model specifications i.e. (1) different measurements of disaster preparedness actions; and (2) estimation strategies. This ensures the robustness of our findings.

As expected, having experienced loss and damages from previous disasters increases disaster preparedness. In fact, prior disaster experience, which is influenced by geographical location of the home, is one of the key predictors of the adoption of precautionary measures. Once being affected by a disaster, it seems that people acquired understanding of the devastation that disasters can create and hence obtained knowledge of what they can do to minimize the risk of harm (Sattler et al., 2000). In this regard, education does not seem to play a significant role since anyone who was affected by a disaster had a chance to learn about the risks of natural hazards. 
Interestingly though, among those who have not previously been affected by a disaster, educational attainment becomes a key determinant of adoption of preparedness measures. Since more years of schooling is related to improved abstract reasoning and anticipation skills (Baker et al., 2011; Blair et al., 2005; Ceci, 1991; Nisbett, 2010), highly educated individuals do not need to experience a disaster to understand that disasters can be devastating. Indeed, this finding is in line with previous studies on the relationship between education and health behaviors. For instance, people with higher years of education can anticipate the harm of smoking without needing to first light up many cigarettes, become ill, and later quit smoking (de Walque, 2007). Thus, education seems to provide a protective effect against natural disaster threats.

Taking a broader perspective on education, there is another interesting notion to our findings. Since disaster shocks are likely to be correlated among neighboring households, the effect of having experienced a disaster could not only be driven by individual learning about disaster risks and mitigation, but also by non-formal or social learning in the affected communities. If several households in an area are affected by a disaster, there may be a stronger tendency to exchange experiences and to undertake effective joint actions to prepare against future disaster events. These sort of complementarities and spillovers may lead to an amplification of the observed experience effects. In fact, based on the Philippine data, we also find evidence that parental education matters for the adoption of precautionary measures which might as well speak for the importance of informal education in this context. Although we cannot trace back the exact mechanisms underlying the effects in this paper, our main argument holds: in the absence of previous disaster experiences and hence without possibilities for individual or social learning, formal education is an effective way in raising personal and household disaster preparedness.

Regarding the channels through which education influences disaster preparedness in both the Philippines and Thailand, rather surprisingly, income does not play a particularly important role in determining preparedness actions. We expected that specifically in the considered low- and middle-income country contexts where government investment in disaster mitigation and risk management is relatively low (Jha \& Stanton-Geddes, 2013), individuals and households have to rely on their own financial resources in implementing preparedness actions. Thus, income should be an important determinant of disaster preparedness. One explanation for this finding is possibly that most preparedness actions undertaken by our respondents in the Philippines and Thailand such as storing food or having a family emergency plan do not require much financial investment. Therefore, in such context, income does not necessarily influence disaster preparedness.

An alternative explanation is that income truly plays a minor role in disaster risk reduction. While the previous literature commonly highlighted the role of income on natural disaster risk and impacts (Kahn, 2005; Kellenberg \& Mobarak, 2008), a series of new empirical evidence has shown that education has a stronger effect than income on reducing vulnerability to natural disasters (Muttarak \& Lutz, 2014). Toya and Skidmore (2007), for instance, find that educational attainment has stronger effects than Gross Domestic Product (GDP) per capita in determining life and economic losses due to natural disasters in a macro analysis of 151 countries. Consistently, decomposing the Human Development Index (HDI) impact on mortality from natural disasters, Striessnig, Lutz, and Patt (2013) were able to pinpoint that it was female education that explains lower disaster mortality rather than
GDP. Similarly, at the micro level, it was found that community, household and individual education levels are the main factors explaining disaster preparedness, responses and losses while income does not have any significant effect (KC, 2013; Muttarak \& Pothisiri, 2013; Sharma, Patwardhan, \& Patt, 2013). Our results also point to a similar direction. Here education plays a greater role in reducing vulnerability than income possibly because education is key in enhancing abstract reasoning and anticipation skills which are important both for obtaining better income and improving resilience.

Furthermore, we find that how education promotes disaster preparedness is context-specific. In the Philippines, it appears that none of the possible mediating factors explain the effect of education on preparedness behavior. In Thailand, we found that the highly educated have higher perceptions of disaster risks that can occur in a community as well as higher social capital which in turn increase disaster preparedness. These discrepancies between the two countries may have to do with different sampling designs of the two surveys. While respondents in the Philippines are based in the capital, Manila, the Thai sample comes from more rural settings. It has been shown that social capital has stronger influence on life outcomes in a rural context than in an urban environment (Hofferth \& Iceland, 1998). Therefore, particularly in Thailand, social capital as measured by social participation plays an important role in explaining education effects on disaster preparedness since this may provide a platform for community members to exchange information including disaster-related knowledge.

Like many other studies which rely on cross-sectional survey data, this study has four main limitations. First, the study relies on self-reported measures of preparedness actions which may be overstated by the respondents due to social desirability bias. It is possible that individuals with higher level of education over-report their preparedness behavior in order to present themselves in a positive way following socially accepted standards. A different type of research design such as an observational study is thus required to assess patterns in reporting bias. Second, due to the cross-sectional nature of our data, we are unable to make causal claims on the relationship between education, disaster experience, and preparedness actions. Longitudinal and quasi-experimental data can contribute to the identification of causal effects and to a better understanding of the underlying processes leading to disaster preparedness. Third, not all variables used in the analysis are measured in the same way in the two samples. In particular, different dimensions of social capital are captured, which may explain the diverse effect of social capital on disaster preparedness in the two countries. Nevertheless, we argue that the variable social support in the Philippines and civic engagement in Thailand both represent embeddedness in social networks, which can be useful in promoting disaster preparedness. Fourth, as mentioned above, the two cases and samples used in this study may not be perfectly comparable with the survey in the Philippines focusing on a sample of women living in an urban area while the Thai survey includes both men and women covering three provinces in different parts of Thailand. Likewise, the two countries are also exposed to different natural disaster risks which can influence both the necessity to take individual preparedness measures and the type of actions taken. Nevertheless, the main aim of this study is not to compare between the two countries but to scrutinize the effects of education on preparedness behavior, which have been shown to be highly relevant in both settings.

Although our findings on the mechanisms underlying the role of education on disaster preparedness may not be generalizable, we have empirically shown the possible pathways 
through which education can influence preparedness actions. Further investigations using better data sources (e.g., longitudinal data and nationally representative surveys) or alternative techniques (e.g., natural experiments such as educational reforms) would make a more rigorous identification of the causal pathways between education and preventive behavior possible. Likewise, more refined measurement of education including quality of schooling and curriculums would be useful to pinpoint which dimension of education matters most in promoting desirable behavior.

Despite the limitations, this study contributes to research on disaster risk reduction in three important ways. First, we provide new insights into the role of education in improving abstract reasoning and anticipation skills. By examining the interplay between formal schooling and disaster experience, we have shown that education can substitute disaster experience in promoting the take-up of precautionary measures. In other words, educated individuals can anticipate disaster risks without having to be affected by a disaster first. Second, we extend beyond the current literature which has found that education can reduce vulnerability through reducing disaster mortality (Lutz, Muttarak, \& Striessnig, 2014; Striessnig et al., 2013), injury (Frankenberg, Sikoki, Sumantri, Suriastini, \& Thomas, 2013), and asset and income lost (KC, 2013), as well as improving coping capacity after a disaster (Garbero \& Muttarak, 2013; Helgeson, Dietz, \& Hochrainer-Stigler, 2013). Not only that our study shows that education increases preparedness actions but also identifies the underlying mechanisms through which education contributes to disaster pre- paredness. To our knowledge, this has not yet been done at least in the vulnerability literature. Third, not only there are relatively few studies on disaster preparedness focusing on low- and middle-income countries, comparative studies are even scarcer. This study thus provides new empirical evidence comparing disaster preparedness in two disaster-prone countries in Southeast Asia.

In this study, we have empirically shown that in the absence of disaster experience, formal education plays a key role in promoting preparedness actions. This is an example of positive externalities of investing in human capital which extends to the aspect of vulnerability reduction. Certainly, it remains important for national governments to invest in disaster risk reduction measures such as early warning systems or evacuation centers. However, it seems evident that public funding in universal education will also benefit precautionary behavior at the personal and household level. Indeed, recent documents and statements from UN agencies such as the UNISDR (United Nations Office for Disaster Risk Reduction) and the UNESCO (United Nations Educational, Scientific and Cultural Organization) have put forward the role of education in promoting sustainable development and in building resilience, in particular (UNESCO Bangkok, 2007; UNESCO, 2016; UNISDR, 2015). Our study has provided solid empirical evidence confirming the important role education plays in reducing disaster risk as well as added to the understanding of the mechanisms through which education contributes to increasing household disaster resilience.

\section{REFERENCES}

Ablah, E., Konda, K., \& Kelley, C. L. (2009). Factors predicting individual emergency preparedness: A multi-state analysis of 2006 BRFSS data. Biosecurity and Bioterrorism, 7(3), 317-330. http://dx. doi.org/10.1089/bsp.2009.0022.

Adiyoso, W., \& Kanegae, H. (2014). The role of Islamic teachings in encouraging people to take tsunami preparedness in Aceh and Yogyakarta Indonesia. In R. Shaw (Ed.), Recovery from the Indian Ocean Tsunami: A Ten-Year Journey (pp. 259-278). Tokyo: Springer Japan.

Allen, K. M. (2006). Community-based disaster preparedness and climate adaptation: Local capacity-building in the Philippines. Disasters, 30(1), 81-101. http://dx.doi.org/10.1111/j.1467-9523.2006.00308.x.

Al-Rousan, T. M., Rubenstein, L. M., \& Wallace, R. B. (2014). Preparedness for natural disasters among older US adults: A nationwide survey. American Journal of Public Health, 104(3), 506-511. http://dx.doi.org/10.2105/AJPH.2013.301559.

Andrews, R. J., \& Quintana, L. M. (2015). Unpredictable, unpreventable and impersonal medicine: Global disaster response in the 21 st century. The EPMA Journal, 6(1), 2. http://dx.doi.org/10.1186/s13167-0140024-9.

Baker, E. J. (1980). Coping with hurricane evacuation difficulties. Gainesville, Florida: Florida Sea Grant College Conference Report No. 33: Hurricane and Coastal Storms.

Baker, E. J. (2011). Household preparedness for the aftermath of Hurricanes in Florida. Applied Geography, 31(1), 46-52. http://dx. doi.org/10.1016/j.apgeog.2010.05.002.

Baker, D. P., Leon, J., Smith Greenaway, E. G., Collins, J., \& Movit, M. (2011). The education effect on population health: A reassessment. Population and Development Review, 37(2), 307-332. http://dx.doi.org/ 10.1111/j.1728-4457.2011.00412.x.

Bangkok, U. N. E. S. C. O. (2007). Natural disaster preparedness and education for sustainable development. Bangkok: UNESCO Asia and Pacific Regional Bureau for Education, Retrieved from http://unesdoc. unesco.org/images/0015/001504/150454e.pdf.

Barakat, B., Bengtsson, S., Muttarak, R., \& Kebede, E. B. (2016). Education \& the sustainable development goals (background paper prepared for the 2016 global education monitoring report). Paris:
UNESCO, Retrieved from http://unesdoc.unesco.org/images/0024/ 002455/245580E.pdf.

Basolo, V., Steinberg, L. J., Burby, R. J., Levine, J., Cruz, A. M., \& Huang, C. (2009). The effects of confidence in government and information on perceived and actual preparedness for disasters. Environment and Behavior, 41(3), 338-364. http://dx.doi.org/10.1177/ 0013916508317222.

Basten, S., Muttarak, R., \& Pothisiri, W. (2014). "The persistence of parent repayment" and the anticipation of filial obligations of care in two thai provinces. Asian Social Work and Policy Review, 8(2), 109-122. http://dx.doi.org/10.1111/aswp.12028.

Benzion, U., Rapoport, A., \& Yagil, J. (1989). Discount rates inferred from decisions: An experimental study. Management Science, 35, 270-284. http://dx.doi.org/10.1287/mnsc.35.3.270.

Birkmann, J., Buckle, P., Jaeger, J., Pelling, M., Setiadi, N., Garschagen, M., ... Kropp, J. (2008). Extreme events and disasters: A window of opportunity for change? Analysis of organizational, institutional and political changes, formal and informal responses after mega-disasters. Natural Hazards, 55(3), 637-655. http://dx.doi.org/10.1007/s11069008-9319-2.

Blair, C., Gamson, D., Thorne, S., \& Baker, D. (2005). Rising mean IQ: Cognitive demand of mathematics education for young children, population exposure to formal schooling, and the neurobiology of the prefrontal cortex. Intelligence, 33(1), 93-106. http://dx.doi.org/ 10.1016/j.intell.2004.07.008.

Boscarino, J. A., Adams, R. E., Figley, C. R., Galea, S., \& Foa, E. B. (2006). Fear of terrorism and preparedness in New York City 2 years after the attacks: Implications for disaster planning and research. Journal of Public Health Management and Practice: JPHMP, 12(6), 505-513.

Bourque, L. B., Mileti, D. S., Kano, M., \& Wood, M. M. (2012). Who prepares for terrorism?. Environment and Behavior, 44(3), 374-409. http://dx.doi.org/10.1177/0013916510390318.

Brower, R. S., Magno, F. A., \& Dilling, J. (2014). Evolving and implementing a new disaster management paradigm: The case of the Philippines. In N. Kapucu, \& K. T. Liou (Eds.), Disaster and development (pp. 289-313). Springer International Publishing. 
Brunello, G., Fort, M., Schneeweis, N., \& Winter-Ebmer, R. (2015). The causal effect of education on health: What is the role of health behaviors?. Health Economics. http://dx.doi.org/10.1002/hec.3141.

Bubeck, P., Botzen, W. J. W., Kreibich, H., \& Aerts, J. C. J. H. (2013). Detailed insights into the influence of flood-coping appraisals on mitigation behaviour. Global Environmental Change, 23(5), 1327-1338. http://dx.doi.org/10.1016/j.gloenvcha.2013.05.009.

Burby, R. J., Steinberg, L. J., \& Basolo, V. (2003). The tenure trap: The vulnerability of renters to joint natural and technological disasters. Urban Affairs Review, 39(1), 32-58. http://dx.doi.org/10.1177/ 1078087403253053

Card, D. (1999). The causal effect of education on earnings. In O. C. A Card, \& David (Eds.). Handbook of labor economics (Vol. 3, Part A, pp. 1801-1863). Elsevier.

Ceci, S. J. (1991). How much does schooling influence general intelligence and its cognitive components? A reassessment of the evidence. Developmental Psychology, 27(5), 703-722. http://dx.doi.org/10.1037/ 0012-1649.27.5.703.

Centre for Research on the Epidemiology of Disasters (2015). Annual disaster statistical review 2014: The numbers and trends.

Chankrajang, T., \& Muttarak, R. (2017). Green returns to education: Does schooling contribute to pro-environmental behaviours? Evidence from Thailand. Ecological Economics, 131, 434-448. http://dx.doi.org/ 10.1016/j.ecolecon.2016.09.015.

Chew, S. H., Heckman, J., Yi, J., Zhang, J., \& Zhong, S. (2010). Education and preferences: Experimental evidence from Chinese adult twins. Chicago, USA.

Coleman, J. S. (1988). Social capital in the creation of human capital. American Journal of Sociology, 94, S95-S120.

Coombs, P. H., Prosser, R., \& Ahmed, M. (1973). New paths to learning for rural children and youth. International Council for Educational Development.

Cotten, S. R., \& Gupta, S. S. (2004). Characteristics of online and offline health information seekers and factors that discriminate between them. Social Science \& Medicine, 59(9), 1795-1806. http://dx.doi.org/ 10.1016/j.socscimed.2004.02.020.

Cutler, D. M., \& Lleras-Muney, A. (2010). Understanding differences in health behaviors by education. Journal of Health Economics, 29(1), 1-28. http://dx.doi.org/10.1016/j.jhealeco.2009.10.003.

de Bruin, W., Parker, A. M., \& Fischhoff, B. (2007). Individual differences in adult decision-making competence. Journal of Personality and Social Psychology, 92(5), 938-956. http://dx.doi.org/10.1037/00223514.92.5.938

de Walque, D. (2007). Does education affect smoking behaviors? Evidence using the Vietnam draft as an instrument for college education. Journal of Health Economics, 26(5), 877-895. http://dx.doi.org/10.1016/j. jhealeco.2006.12.005.

de Walque, D. (2010). Education, information, and smoking decisions evidence from smoking histories in the United States, 1940-2000. Journal of Human Resources, 45(3), 682-717. http://dx.doi.org/ 10.3368/jhr.45.3.682.

Dohmen, T., Falk, A., Huffman, D., Sunde, U., Schupp, J., \& Wagner, G. G. (2011). Individual risk attitudes: Measurement, determinants, and behavioral consequences. Journal of the European Economic Association, 9, 522-550. http://dx.doi.org/10.1111/j.1542-4774.2011.01015.x.

Eisenman, D. P., Zhou, Q., Ong, M., Asch, S., Glik, D., \& Long, A. (2009). Variations in disaster preparedness by mental health, perceived general health, and disability status. Disaster Medicine and Public Health Preparedness, 3(1), 33-41. http://dx.doi.org/10.1097/ DMP.0b013e318193be89.

EM-DAT (2015). EM-DAT database. Centre for Research on the Epidemiology of Disasters - CRED, Retrieved November 10, 2015, from <www.emdat.be/database $>$.

Eslinger, P. J., Blair, C., Wang, J., Lipovsky, B., Realmuto, J., Baker, D., Yang, Q. X. (2009). Developmental shifts in FMRI activations during visuospatial relational reasoning. Brain and Cognition, 69(1), 1-10. http://dx.doi.org/10.1016/j.bandc.2008.04.010.

Faupel, C. E., Kelly, S. P., \& Petee, T. (1992). The impact of disaster education on household preparedness for Hurricane Hugo. Interna tional Journal of Mass Emergencies and Disasters, 10(1), 5-24. http:// dx.doi.org/10.1177/0013916593252004.

Field, C. B., Barros, V., Stocker, T., Dahe, Q., Dokken, D. J., Ebi, K. L., \& Mastrandrea, M. D. (2012). Managing the risks of extreme events and disasters to advance climate change adaptation. New York: Cambridge University Press.
Frankenberg, E., Sikoki, B., Sumantri, C., Suriastini, W., \& Thomas, D. (2013). Education, vulnerability, and resilience after a natural disaster. Ecology and Society, 18(2). http://dx.doi.org/10.5751/ES-05377180216.

Garbero, A., \& Muttarak, R. (2013). Impacts of the 2010 droughts and floods on community welfare in rural Thailand: Differential effects of village educational attainment. Ecology and Society, 18(4), 27. http:// dx.doi.org/10.5751/ES-05871-180427.

Gathmann, C., Jürges, H., \& Reinhold, S. (2014). Compulsory schooling reforms, education and mortality in twentieth century Europe. Social Science \& Medicine, 127, 74-82. http://dx.doi.org/10.1016/j.socscimed.2014.01.037.

Grossman, M. (2006). Education and nonmarket outcomes. In E. Hanushek, \& F. Welch (Eds.). Handbook of the economics of education (Vol. 1).

Harvatt, J., Petts, J., \& Chilvers, J. (2011). Understanding householder responses to natural hazards: Flooding and sea-level rise comparisons. Journal of Risk Research, 14(1), 63-83. http://dx.doi.org/10.1080/ 13669877.2010 .503935$.

Hausman, A. J., Hanlon, A., \& Seals, B. (2007). Social capital as a mediating factor in emergency preparedness and concerns about terrorism. Journal of Community Psychology, 35(8), 1073-1083. http:// dx.doi.org/10.1002/jcop.20203.

Helgeson, J. F., Dietz, S., \& Hochrainer-Stigler, S. (2013). Vulnerability to weather disasters: The choice of coping strategies in rural Uganda. Ecology and Society, 18(2), 2. http://dx.doi.org/10.5751/ES-05390180202.

Heller, K., Alexander, D. B., Gatz, M., Knight, B. G., \& Rose, T. (2005). Social and personal factors as predictors of earthquake preparation: The role of support provision, network discussion, negative affect, age, and education. Journal of Applied Social Psychology, 35(2), 399-422.

Hofferth, S. L., \& Iceland, J. (1998). Social capital in rural and urban communities. Rural Sociology, 63(4), 574-598. http://dx.doi.org/ 10.1111/j.1549-0831.1998.tb00693.x.

Horney, J., Snider, C., Malone, S., Gammons, L., \& Ramsey, S. (2008). Factors associated with hurricane preparedness: Results of a prehurricane assessment. Journal of Disaster Research, 3(2), 143-149.

Huang, J., van den Brink, H., \& Groot, W. (2009). A meta-analysis of the effect of education on social capital. Economics of Education Review, 28 (4), 454-464. http://dx.doi.org/10.1016/j.econedurev.2008.03.004.

Jackson, E. L. (1981). Response to earthquake hazard: The West Coast of North America. Environment and Behavior, 13(4), 387-416. http://dx. doi.org/10.1177/0013916581134001.

Jha, A. K., \& Stanton-Geddes, Z. (Eds.) (2013). Strong, safe, and resilient: A strategic policy guide for disaster risk management in East Asia and the Pacific. Washington, DC: World Bank Publications.

Kahn, M. E. (2005). The death toll from natural disasters: The role of income, geography, and institutions. Review of Economics and Statistics, 87(2), 271-284. http://dx.doi.org/10.1162/0034653053970339.

Karanci, A. N., Aksit, B., \& Dirik, G. (2005). Impact of a community disaster awareness training program in Turkey: Does it influence hazard-related cognitions and preparedness behaviors. Social Behavior and Personality: An International Journal, 33(3), 243-258. http://dx. doi.org/10.2224/sbp.2005.33.3.243.

Karlson, K. B., Holm, A., \& Breen, R. (2012). Comparing regression coefficients between same-sample nested models using logit and probit a new method. Sociological Methodology, 42(1), 286-313. http://dx. doi.org/10.1177/0081175012444861.

KC, S. (2013). Community vulnerability to floods and landslides in Nepal. Ecology and Society, 18(1). http://dx.doi.org/10.5751/ES-05095180108.

Kellenberg, D. K., \& Mobarak, A. M. (2008). Does rising income increase or decrease damage risk from natural disasters? Journal of Urban Economics, 63(3), 788-802. http://dx.doi.org/10.1016/j. jue.2007.05.003.

Kenkel, D. S. (1991). Health behavior, health knowledge, and schooling. Journal of Political Economy, 99(2), 287. http://dx.doi.org/10.1086/ 261751

Kim, Y.-C., \& Kang, J. (2010). Communication, neighbourhood belonging and household hurricane preparedness. Disasters, 34(2), 470-488. http://dx.doi.org/10.1111/j.1467-7717.2009.01138.x.

Kirkby, A. V. (1974). Individual and community responses to rainfall variability in Oaxaca, Mexico. In G. F. White (Ed.), Natural Hazards: Local, National, Global (pp. 119-128). New York: Wiley. 
Kirschenbaum, A. (2006). Families and disaster behavior: A reassessment of family preparedness. International Journal of Mass Emergencies and Disasters, 24(1), 111-143.

Kohn, S., Eaton, J. L., Feroz, S., Bainbridge, A. A., Hoolachan, J., \& Barnett, D. J. (2012). Personal disaster preparedness: An integrative review of the literature. Disaster Medicine and Public Health Preparedness, 6(3), 217-231. http://dx.doi.org/10.1001/dmp.2012.47.

Kreft, S., Eckstein, D., Dorsch, L., \& Fischer, L. (2015). global climate risk index 2016: Who suffers most from extreme weather events? Weatherrelated loss events in 2014 and 1995 to 2014. Bonn: Germanwatch, Retrieved from https://germanwatch.org/fr/download/13503.pdf.

Lake, R. L. D., \& Huckfeldt, R. (1998). Social capital, social networks, and political participation. Political Psychology, 19(3), 567-584.

Lave, T. R., \& Lave, L. B. (1991). Public perception of the risks of floods: Implications for communication. Risk Analysis, 11(2), 255-267.

Lawrence, J., Quade, D., \& Becker, J. (2014). Integrating the effects of flood experience on risk perception with responses to changing climate risk. Natural Hazards, 74(3), 1773-1794. http://dx.doi.org/10.1007/ s11069-014-1288-z.

Lee, J. E. C., \& Lemyre, L. (2009). A social-cognitive perspective of terrorism risk perception and individual response in Canada. Risk Analysis, 29(9), 1265-1280. http://dx.doi.org/10.1111/j.15396924.2009.01264.x.

Lindell, M. K., \& Hwang, S. N. (2008). Households' perceived personal risk and responses in a multihazard environment. Risk Analysis, 28(2), 539-556. http://dx.doi.org/10.1111/j.1539-6924.2008.01032.x.

Lindell, M. K., \& Whitney, D. J. (2000). Correlates of household seismic hazard adjustment adoption. Risk Analysis, 20(1), 13-26. http://dx.doi. org/10.1111/0272-4332.00002.

Lutz, W., Muttarak, R., \& Striessnig, E. (2014). Universal education is key to enhanced climate adaptation. Science, 346(6213), 1061-1062. http:// dx.doi.org/10.1126/science.1257975.

Martin, W. E., Martin, I. M., \& Kent, B. (2009). The role of risk perceptions in the risk mitigation process: The case of wildfire in high risk communities. Journal of Environmental Management, 91(2), 489-498. http://dx.doi.org/10.1016/j.jenvman.2009.09.007.

McGee, T. K., \& Russell, S. (2003). "It's just a natural way of lifeellipsis" an investigation of wildfire preparedness in rural Australia. Global Environmental Change Part B: Environmental Hazards, 5(1-2), 1-12. http://dx.doi.org/10.1016/j.hazards.2003.04.001.

McNeill, I. M., Dunlop, P. D., Heath, J. B., Skinner, T. C., \& Morrison, D. L. (2013). Expecting the unexpected: Predicting physiological and psychological wildfire preparedness from perceived risk, responsibility, and obstacles. Risk Analysis, 33(10), 1829-1843. http://dx.doi.org/ 10.1111/risa.12037.

Miceli, R., Sotgiu, I., \& Settanni, M. (2008). Disaster preparedness and perception of flood risk: A study in an alpine valley in Italy. Journal of Environmental Psychology, 28(2), 164-173. http://dx.doi.org/10.1016/ j.jenvp.2007.10.006.

Mileti, D. S., Fitzpatrick, C., \& Farhar, B. C. (1992). Fostering public preparations for natural hazards: Lessons from the Parkfield earthquake prediction. Environment: Science and Policy for Sustainable Development, 34(3), 16-39. http://dx.doi.org/10.1080/ 00139157.1992.9931434.

Mishra, S., \& Suar, D. (2007). Do lessons people learn determine disaster cognition and preparedness?. Psychology \& Developing Societies, 19(2), 143-159. http://dx.doi.org/10.1177/097133360701900201.

Murphy, S. T., Cody, M., Frank, L. B., Glik, D., \& Ang, A. (2009). Predictors of emergency preparedness and compliance. Disaster Medicine and Public Health Preparedness. http://dx.doi.org/10.1097/ DMP.0b013e3181a9c6c5.

Muttarak, R., \& Lutz, W. (2014). Is education a key to reducing vulnerability to natural disasters and hence unavoidable climate change?. Ecology and Society, 19(1), 42. http://dx.doi.org/10.5751/ ES-06476-190142.

Muttarak, R., \& Pothisiri, W. (2013). The role of education on disaster preparedness: Case study of 2012 Indian Ocean earthquakes on Thailand's Andaman coast. Ecology and Society, 18(4), 51. http://dx. doi.org/10.5751/ES-06101-180451.

Neuenschwander, L. M., Abbott, A., \& Mobley, A. R. (2012). Assessment of low-income adults' access to technology: Implications for nutrition education. Journal of Nutrition Education and Behavior, 44(1), 60-65. http://dx.doi.org/10.1016/j.jneb.2011.01.004.

Nisbett, R. E. (2010). Intelligence and how to get it: Why schools and cultures count. New York: W. W. Norton \& Company.
Norris, F. H., Smith, T., \& Kaniasty, K. (1999). Revisiting the experiencebehavior hypothesis: The effects of Hurricane Hugo on hazard preparedness and other self-protective acts. Basic and Applied Social

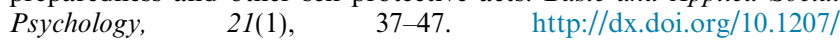
s15324834basp2101 4.

Oberauer, K., Süß, H.-M., Schulze, R., Wilhelm, O., \& Wittmann, W. W. (2000). Working memory capacity - Facets of a cognitive ability construct. Personality and Individual Differences. http://dx.doi.org/ 10.1016/S0191-8869(99)00251-2.

Oreopoulos, P., \& Salvanes, K. G. (2011). Priceless: The nonpecuniary benefits of schooling. Journal of Economic Perspectives, 25(1), 159-184. http://dx.doi.org/10.1257/jep.25.1.159.

Paton, D., \& Johnston, D. (2001). Disasters and communities: Vulnerability, resilience and preparedness. Disaster Prevention and Management, 10(4), 270-277. http://dx.doi.org/10.1108/EUM0000000005930.

Paton, D., Millar, M., \& Johnston, D. (2001). Community resilience to volcanic hazard consequences. Natural Hazards, 24(2), 157-169. http:// dx.doi.org/10.1023/A:1011882106373.

Paul, B. K., \& Bhuiyan, R. H. (2010). Urban earthquake hazard: Perceived seismic risk and preparedness in Dhaka City. Bangladesh. Disasters, 34(2), 337-359. http://dx.doi.org/10.1111/j.1467. 7717.2009.01132.x.

Pérez-Arce, F. (2011). The effect of education on time preferences. NY: Rochester.

Peters, E., Västfjäll, D., Slovic, P., Mertz, C. K., Mazzocco, K., \& Dickert, S. (2006). Numeracy and decision making. Psychological Science, 17(5) , 407-413. http://dx.doi.org/10.1111/j.1467-9280.2006.01720.x.

Phillips, B. D., Metz, W. C., \& Nieves, L. A. (2005). Disaster threat: Preparedness and potential response of the lowest income quartile. Environmental Hazards, 6(3), 123-133. http://dx.doi.org/10.1016/j.hazards.2006.05.001.

Quartz, S. R., \& Sejnowski, T. J. (1997). The neural basis of cognitive development: A constructivist manifesto. The Behavioral and Brain Sciences, 20(4), 537-596.

Reininger, B. M., Rahbar, M. H., Lee, M., Chen, Z., Alam, S. R., Pope, J., \& Adams, B. (2013). Social capital and disaster preparedness among low income Mexican Americans in a disaster prone area. Social Science \& Medicine, 83, 50-60. http://dx.doi.org/10.1016/j.socscimed.2013.01.037.

Republic of the Philippines (2011). The National Disaster Risk Reduction and Management Plan (NDRRMP) Retrieved fromhttp://www. dilg.gov.ph/PDF_File/reports_resources/DILG-Resources-2012116420 ac59e31.pdf.

Richardson, L. D., \& Wolfe, M. (Eds.) (2001). Principles and Practice of Informal Education. London; New York: Routledge.

Rodriguez, H., Diaz, W., Santos, J. M., \& Aguirre, B. E. (2007). Communicating risk and uncertainty: Science, technology, and disasters at the crossroads. In Handbook of Disaster Research (pp. 476-488). New York: Springer.

Russell, L. A., Goltz, J. D., \& Bourque, L. B. (1995). Preparedness and hazard mitigation actions before and after two earthquakes. Environment and Behavior, 27(6), 744-770. http://dx.doi.org/10.1177/ 0013916595276002.

Sattler, D. N., Kaiser, C. F., \& Hittner, J. B. (2000). Disaster preparedness: Relationships among prior experience, personal characteristics, and distress. Journal of Applied Social Psychology, 30(7), 1396-1420. http://dx.doi.org/10.1111/j.1559-1816.2000.tb02527.x.

Sharma, U., Patwardhan, A., \& Patt, A. G. (2013). Education as a determinant of response to cyclone warnings: Evidence from coastal zones in India. Ecology and Society, 18(2). http://dx.doi.org/10.5751/ ES-05439-180218.

Shelley, M. K. (1993). Outcome signs, question frames and discount rates. Management Science. http://dx.doi.org/10.1287/mnsc.39.7.806.

Shreve, C. M., \& Kelman, I. (2014). Does mitigation save? Reviewing cost-benefit analyses of disaster risk reduction. International Journal of Disaster Risk Reduction, 10(Part A), 213-235. http://dx.doi.org/ 10.1016/j.ijdrr.2014.08.004.

Siegel, J. M., Shoaf, K. I., Afifi, A. A., \& Bourque, L. B. (2003). Surviving two disasters: Does reaction to the first predict response to the second? Environment and Behavior, 35(5), 637-654. http://dx.doi.org/10.1177/ 0013916503254754.

Siegrist, M., \& Gutscher, H. (2008). Natural hazards and motivation for mitigation behavior: People cannot predict the affect evoked by a severe flood. Risk Analysis: An Official Publication of the Society for 
Risk Analysis, 28(3), 771-778. http://dx.doi.org/10.1111/j.15396924.2008.01049.x.

Sims, J. H., \& Baumann, D. D. (1983). Educational programs and human response to natural hazards. Environment and Behavior, 15(2), 165-189. http://dx.doi.org/10.1177/0013916583152003.

Smith, D. L., \& Notaro, S. J. (2009). Personal emergency preparedness for people with disabilities from the 2006-2007 Behavioral Risk Factor Surveillance System. Disability and Health Journal, 2(2), 86-94. http:// dx.doi.org/10.1016/j.dhjo.2009.01.001.

Solberg, C., Rossetto, T., \& Joffe, H. (2010). The social psychology of seismic hazard adjustment: Re-evaluating the international literature. Natural hazards and earth system sciences Journal, 10(8), 1663-1677. http://dx.doi.org/10.5194/nhess-10-1663-2010.

Sorensen, J. H. (1983). Knowing how to behave under the threat of disaster can it be explained?. Environment and Behavior, 15(4), 438-457. http://dx.doi.org/10.1177/0013916583154003.

Spittal, M. J., McClure, J., Siegert, R. J., \& Walkey, F. H. (2008). Predictors of two types of earthquake preparation: Survival activities and mitigation activities. Environment and Behavior, 40(6), 798-817. http://dx.doi.org/10.1177/0013916507309864.

Striessnig, E., Lutz, W., \& Patt, A. G. (2013). Effects of educational attainment on climate risk vulnerability. Ecology and Society, 18(1). http://dx.doi.org/10.5751/ES-05252-180116.

Tanaka, K. (2005). The impact of disaster education on public preparation and mitigation for earthquakes: A cross-country comparison between Fukui, Japan and the San Francisco Bay Area, California. USA. Applied Geography, 25(3), 201-225. http://dx.doi.org/10.1016/j.apgeog.2005.07.001

Tekeli-Yeşil, S., Dedeoğlu, N., Tanner, M., Braun-Fahrlaender, C., \& Obrist, B. (2010). Individual preparedness and mitigation actions for a predicted earthquake in Istanbul. Disasters, 34(4), 910-930. http://dx. doi.org/10.1111/j.1467-7717.2010.01175.x.

Thieken, A. H., Kriebich, H., Müller, M., \& Merz, B. (2007). Coping with floods: Preparedness, response and recovery of flood-affected residents in Germany in 2002. Hydrological Sciences Journal, 52(5), 1016-1037. http://dx.doi.org/10.1623/hysj.52.5.1016.

Toya, H., \& Skidmore, M. (2007). Economic development and the impacts of natural disasters. Economics Letters, 94(1), 20-25. http://dx.doi.org/ 10.1016/j.econlet.2006.06.020.
UNESCO (2016). Education for people and planet: Creating sustainable futures for all (Global Education Monitoring Report 2016). Paris, France: United Nations.

UNISDR (2015). Disaster risk reduction and resilience in the 2030 agenda for sustainable development. Geneva, Switzerland: The United Nations Office for Disaster Risk Reduction (UNISDR), Retrieved from $<$ http://www.unisdr.org/files/46052 disasterriskreductioninthe2030agend.pdf>.

van der Keur, P., van Bers, C., Henriksen, H. J., Nibanupudi, H. K., Yadav, S., Wijaya, R., ... Jaspers, F. (2016). Identification and analysis of uncertainty in disaster risk reduction and climate change adaptation in South and Southeast Asia. International Journal of Disaster Risk Reduction, 16, 208-214. http://dx.doi.org/10.1016/j.ijdrr.2016.03.002.

Wen, L. M., Rissel, C., Baur, L. A., Lee, E., \& Simpson, J. M. (2011). Who is NOT likely to access the Internet for health information? Findings from first-time mothers in southwest Sydney. Australia. International Journal of Medical Informatics, 80(6), 406-411. http://dx. doi.org/10.1016/j.ijmedinf.2011.03.001.

Witvorapong, N., Muttarak, R., \& Pothisiri, W. (2015). social participation and disaster risk reduction behaviors in tsunami prone areas. PLoS One, 10(7), e0130862. http://dx.doi.org/10.1371/journal. pone. 0130862.

Wood, M. M., Mileti, D. S., Kano, M., Kelley, M. M., Regan, R., \& Bourque, L. B. (2012). Communicating actionable risk for terrorism and other hazards. Risk Analysis: An Official Publication of the Society for Risk Analysis, 32(4), 601-615. http://dx.doi.org/10.1111/j.15396924.2011.01645.x.

Xiao, C., \& McCright, A. M. (2007). Environmental concern and sociodemographic variables: A study of statistical models. The Journal of Environmental Education, 38(2), 3-14. http://dx.doi.org/10.3200/ JOEE.38.1.3-14.

Table 5. Measurement and summary statistics for dependent and independent variables

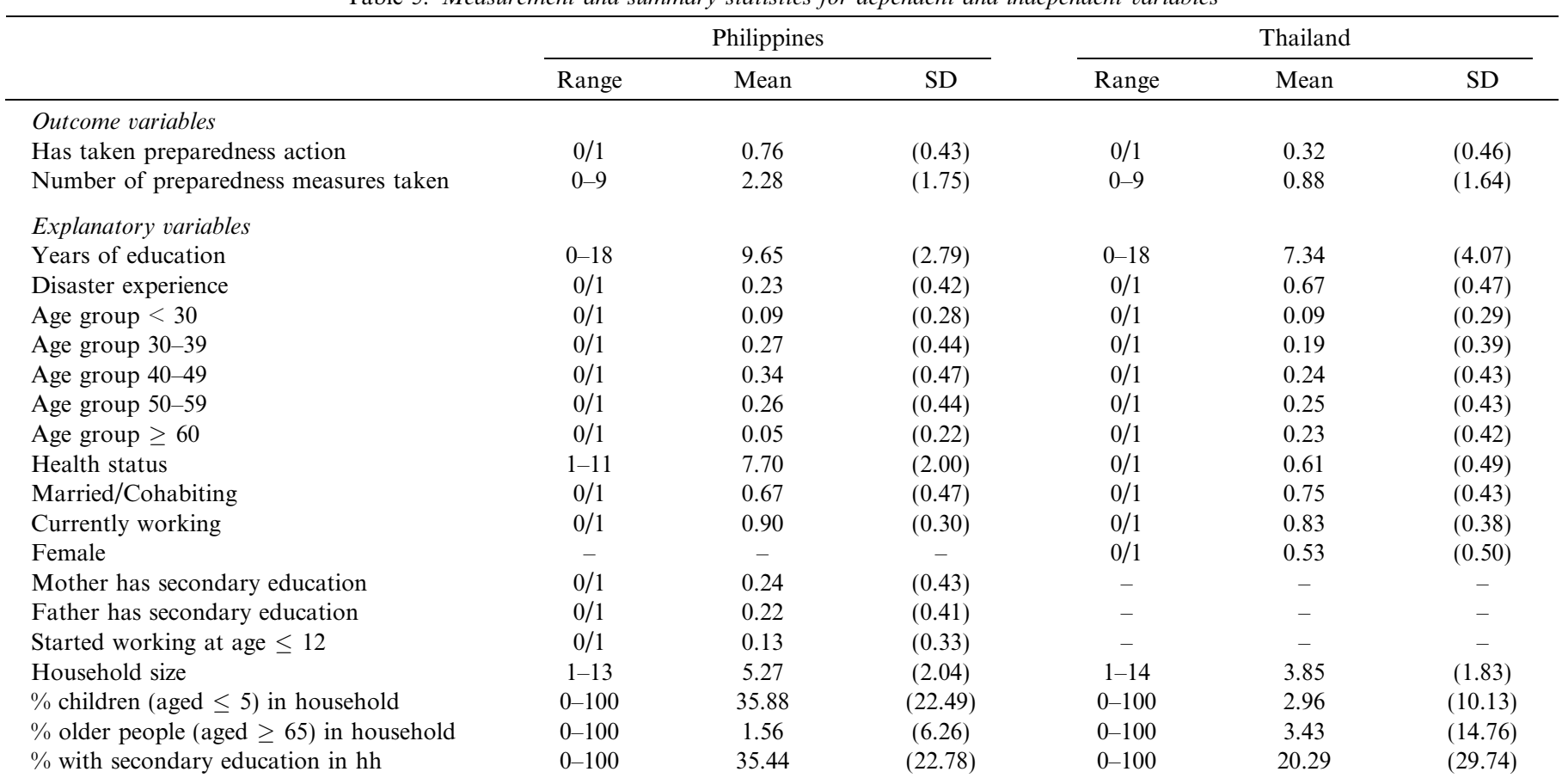


Years of residence

Own house

Own land

House located near coast $(<1 \mathrm{~km})$

House located near river $(<200 \mathrm{~m})$

House located near mountain $(<200 \mathrm{~m})$

Area 1 (PH: Batasan, TH: Phang Nga)

Area 2 (PH: Montalban, TH: Ayutthaya)

Area 3 (PH: Masinag, TH: Kalasin)

Mediating factors

Income

Word recall

Social capital

Future orientation

Risk attitude

Low risk of disaster in community

Moderate risk of disaster in community

High risk of disaster in community

Felt impact of climate change on family

$\begin{array}{cc}0-75 & 18.29 \\ - & - \\ - & - \\ - & - \\ 0 / 1 & 0.45 \\ 0 / 1 & 0.09 \\ 0 / 1 & 0.30 \\ 0 / 1 & 0.36 \\ 0 / 1 & 0.34 \\ & \\ & \\ 0-15,300 & 1,224.18 \\ 0-10 & 4.13 \\ 0 / 1 & 0.77 \\ 0-10 & 5.3 \\ 0-10 & 6.78\end{array}$

(10.74)

$-$

$0-81$

25.11

$(18.03)$

$(0.32)$

$(0.49)$

$(0.29)$

$(0.42)$

$(0.50)$

$(0.29)$

$(0.46)$

$(0.48)$

$(0.47)$

$0 / 1$

0.62

0.09

0.23

$(0.27)$

$(0.48)$

(0.46)

0.36

0.3

0.34

(0.47)

$(1,269.23)$

(1.45)

$(0.42)$

(3.30)

(2.49)

- -

$0 / 1$

$0 / 250,000$
$0-10$
$0 / 1$
-
-
$0 / 1$
$0 / 1$
$0 / 1$
$0 / 1$

11,327.2

4.88

0.17

$(12,905.5)$

(1.91)

(0.38)

$-$

0.15

0.33

0.52

0.57
$-$

(0.35)

$(0.47)$

$(0.50)$

$(0.50)$

Table 6. Extended ordered logit models for Philippine data (effects of controls reported)

\begin{tabular}{|c|c|c|c|c|c|c|c|}
\hline & 1 & 2 & 3 & 4 & 5 & 6 & 7 \\
\hline \multicolumn{8}{|l|}{ Philippines } \\
\hline Years of education & $\begin{array}{l}1.054^{*} \\
{[0.027]}\end{array}$ & $\begin{array}{l}1.053^{*} \\
{[0.027]}\end{array}$ & $\begin{array}{l}1.053^{*} \\
{[0.027]}\end{array}$ & $\begin{array}{l}1.055^{*} \\
{[0.027]}\end{array}$ & $\begin{array}{l}1.053^{*} \\
{[0.027]}\end{array}$ & $\begin{array}{l}1.058^{*} \\
{[0.027]}\end{array}$ & $\begin{array}{l}1.055^{*} \\
{[0.027]}\end{array}$ \\
\hline Income & & $\begin{array}{c}1.000 \\
{[0.001]}\end{array}$ & & & & & $\begin{array}{c}1.000 \\
{[0.001]}\end{array}$ \\
\hline Future orientation & & & & $\begin{array}{c}1.017 \\
{[0.019]}\end{array}$ & & & $\begin{array}{c}1.013 \\
{[0.018]}\end{array}$ \\
\hline Risk attitude & & & & & $\begin{array}{c}0.979 \\
{[0.026]}\end{array}$ & & $\begin{array}{c}0.981 \\
{[0.027]}\end{array}$ \\
\hline Social capital & & & & & & $\begin{array}{c}1.865^{* * *} \\
{[0.290]}\end{array}$ & $\begin{array}{l}1.862^{* * * *} \\
{[0.292]}\end{array}$ \\
\hline Age group $40-49$ & $\begin{array}{c}1.035 \\
{[0.250]}\end{array}$ & $\begin{array}{l}1.025 \\
{[0.246]}\end{array}$ & $\begin{array}{c}1.049 \\
{[0.251]}\end{array}$ & $\begin{array}{l}1.052 \\
{[0.255]}\end{array}$ & $\begin{array}{c}1.045 \\
{[0.255]}\end{array}$ & $\begin{array}{l}1.084 \\
{[0.249]}\end{array}$ & $\begin{array}{c}1.103 \\
{[0.256]}\end{array}$ \\
\hline Age group 50-59 & $\begin{array}{c}0.774 \\
{[0.210]}\end{array}$ & $\begin{array}{c}0.766 \\
{[0.207]}\end{array}$ & $\begin{array}{c}0.798 \\
{[0.215]}\end{array}$ & $\begin{array}{c}0.787 \\
{[0.213]}\end{array}$ & $\begin{array}{c}0.779 \\
{[0.213]}\end{array}$ & $\begin{array}{c}0.828 \\
{[0.214]}\end{array}$ & $\begin{array}{c}0.85 \\
{[0.220]}\end{array}$ \\
\hline Age group $\geq 60$ & $\begin{array}{c}0.54 \\
{[0.203]}\end{array}$ & $\begin{array}{c}0.541 \\
{[0.204]}\end{array}$ & $\begin{array}{l}0.578 \\
{[0.218]}\end{array}$ & $\begin{array}{c}0.547 \\
{[0.206]}\end{array}$ & $\begin{array}{c}0.546 \\
{[0.208]}\end{array}$ & $\begin{array}{c}0.544 \\
{[0.205]}\end{array}$ & $\begin{array}{c}0.591 \\
{[0.227]}\end{array}$ \\
\hline Health status & $\begin{array}{l}1.064^{*} \\
{[0.032]}\end{array}$ & $\begin{array}{l}1.061^{+} \\
{[0.032]}\end{array}$ & $\begin{array}{l}1.065^{*} \\
{[0.032]}\end{array}$ & $\begin{array}{l}1.062^{*} \\
{[0.032]}\end{array}$ & $\begin{array}{l}1.066^{*} \\
{[0.031]}\end{array}$ & $\begin{array}{l}1.072^{*} \\
{[0.032]}\end{array}$ & $\begin{array}{l}1.071^{*} \\
{[0.032]}\end{array}$ \\
\hline Married/Cohabiting & $\begin{array}{c}1.068 \\
{[0.110]}\end{array}$ & $\begin{array}{l}1.067 \\
{[0.109]}\end{array}$ & $\begin{array}{c}1.063 \\
{[0.111]}\end{array}$ & $\begin{array}{l}1.068 \\
{[0.111]}\end{array}$ & $\begin{array}{c}1.063 \\
{[0.109]}\end{array}$ & $\begin{array}{l}1.051 \\
{[0.110]}\end{array}$ & $\begin{array}{c}1.039 \\
{[0.110]}\end{array}$ \\
\hline Currently working & $\begin{array}{l}1.156 \\
{[0.240]}\end{array}$ & $\begin{array}{l}1.124 \\
{[0.239]}\end{array}$ & $\begin{array}{c}1.176 \\
{[0.238]}\end{array}$ & $\begin{array}{l}1.169 \\
{[0.242]}\end{array}$ & $\begin{array}{l}1.158 \\
{[0.241]}\end{array}$ & $\begin{array}{l}1.098 \\
{[0.228]}\end{array}$ & $\begin{array}{l}1.085 \\
{[0.225]}\end{array}$ \\
\hline Mother has secondary education & $\begin{array}{c}0.948 \\
{[0.178]}\end{array}$ & $\begin{array}{c}0.946 \\
{[0.179]}\end{array}$ & $\begin{array}{c}0.928 \\
{[0.172]}\end{array}$ & $\begin{array}{c}0.944 \\
{[0.177]}\end{array}$ & $\begin{array}{c}0.942 \\
{[0.177]}\end{array}$ & $\begin{array}{c}0.902 \\
{[0.169]}\end{array}$ & $\begin{array}{c}0.874 \\
{[0.163]}\end{array}$ \\
\hline
\end{tabular}




\begin{tabular}{|c|c|c|c|c|c|c|c|}
\hline$\%$ children (aged $\leq 5$ ) in hh & $\begin{array}{l}1.007^{+} \\
{[0.004]}\end{array}$ & $\begin{array}{l}1.008^{+} \\
{[0.004]}\end{array}$ & $\begin{array}{l}1.007^{+} \\
{[0.004]}\end{array}$ & $\begin{array}{l}1.007^{+} \\
{[0.004]}\end{array}$ & $\begin{array}{l}1.007^{+} \\
{[0.004]}\end{array}$ & $\begin{array}{l}1.008^{+} \\
{[0.004]}\end{array}$ & $\begin{array}{l}1.008^{*} \\
{[0.004]}\end{array}$ \\
\hline \multirow[t]{2}{*}{$\%$ older people (aged $\geq 65$ ) in hh } & 0.995 & 0.995 & 0.995 & 0.994 & 0.994 & 0.994 & 0.995 \\
\hline & {$[0.010]$} & {$[0.010]$} & {$[0.010]$} & {$[0.010]$} & {$[0.010]$} & {$[0.010]$} & {$[0.010]$} \\
\hline \multirow[t]{2}{*}{$\%$ with secondary education in hh } & 1.004 & 1.004 & 1.004 & 1.004 & 1.004 & 1.005 & 1.005 \\
\hline & {$[0.004]$} & {$[0.004]$} & {$[0.004]$} & {$[0.004]$} & {$[0.004]$} & {$[0.004]$} & {$[0.004]$} \\
\hline \multirow[t]{2}{*}{ Years of residence } & 1.008 & 1.008 & 1.007 & 1.007 & 1.008 & 1.006 & 1.007 \\
\hline & {$[0.008]$} & {$[0.008]$} & {$[0.008]$} & {$[0.008]$} & {$[0.008]$} & {$[0.008]$} & {$[0.008]$} \\
\hline \multirow[t]{2}{*}{ House located near river } & 0.933 & 0.939 & 0.932 & 0.936 & 0.932 & 0.931 & 0.937 \\
\hline & {$[0.195]$} & {$[0.195]$} & {$[0.194]$} & {$[0.193]$} & {$[0.194]$} & {$[0.189]$} & [0.188] \\
\hline \multirow[t]{2}{*}{ House located near mountain } & 0.862 & 0.862 & 0.861 & 0.860 & 0.866 & 0.861 & 0.86 \\
\hline & {$[0.155]$} & {$[0.155]$} & [0.155] & {$[0.153]$} & {$[0.156]$} & [0.159] & {$[0.157]$} \\
\hline \multirow[t]{2}{*}{ Area 2} & $2.041^{* *}$ & $2.059^{* *}$ & $2.042^{* * *}$ & $2.030^{* *}$ & $2.018^{* *}$ & $2.139^{* * *}$ & $2.132^{* * *}$ \\
\hline & [0.469] & {$[0.472]$} & {$[0.467]$} & {$[0.467]$} & {$[0.468]$} & {$[0.476]$} & {$[0.477]$} \\
\hline \multirow[t]{2}{*}{ Area 3} & 1.34 & 1.326 & 1.353 & 1.344 & 1.337 & 1.369 & 1.363 \\
\hline & {$[0.262]$} & {$[0.260]$} & {$[0.266]$} & {$[0.264]$} & {$[0.261]$} & {$[0.267]$} & {$[0.268]$} \\
\hline$N$ & 872 & 872 & 872 & 872 & 872 & 872 & 872 \\
\hline Pseudo $R^{2}$ & 0.033 & 0.034 & 0.034 & 0.034 & 0.034 & 0.04 & 0.042 \\
\hline $\mathrm{AIC}$ & $2,606.6$ & $2,607.6$ & $2,606.6$ & $2,607.8$ & $2,607.9$ & $2,590.8$ & $2,594.6$ \\
\hline
\end{tabular}

${ }^{+} p<0.1,{ }^{*} p<0.05,{ }^{* *} p<0.01,{ }^{* * *} p<0.001$.

Notes: Cell entries are odds ratios with robust standard errors in parentheses. Standard errors are clustered at the neighborhood level.

Table 7. Extended ordered logit models for Thai data (effects of controls reported)

\begin{tabular}{|c|c|c|c|c|c|c|c|}
\hline & 1 & 2 & 3 & 4 & 5 & 6 & 7 \\
\hline \multicolumn{8}{|l|}{ Thailand } \\
\hline \multirow[t]{2}{*}{ Years of education } & $1.046^{*}$ & $1.052^{*}$ & $1.048^{+}$ & $1.043^{*}$ & $1.042^{+}$ & $1.037^{+}$ & $1.041^{*}$ \\
\hline & {$[0.023]$} & {$[0.021]$} & {$[0.025]$} & {$[0.022]$} & {$[0.022]$} & {$[0.021]$} & {$[0.019]$} \\
\hline Disaster experience & {$[0.752]$} & {$[0.755]$} & {$[0.750]$} & {$[0.685]$} & {$[0.675]$} & {$[0.692]$} & {$[0.594]$} \\
\hline \multirow[t]{2}{*}{ Income } & & 0.994 & & & & & 0.995 \\
\hline & & {$[0.006]$} & & & & & {$[0.006]$} \\
\hline \multirow[t]{2}{*}{ Moderate disaster risk } & & & & $2.411^{* * *}$ & & & $2.306^{* *}$ \\
\hline & & & & {$[0.638]$} & & & {$[0.639]$} \\
\hline \multirow[t]{2}{*}{ High disaster risk } & & & & $2.622^{* * *}$ & & & $2.423^{* *}$ \\
\hline & & & & {$[0.755]$} & & & {$[0.713]$} \\
\hline \multirow[t]{2}{*}{ Felt climate change impact } & & & & & $1.806^{* *}$ & & $1.655^{* *}$ \\
\hline & & & & & {$[0.343]$} & & {$[0.315]$} \\
\hline Age group 30-39 & {$[0.329]$} & {$[0.319]$} & {$[0.328]$} & {$[0.333]$} & {$[0.308]$} & {$[0.330]$} & {$[0.308]$} \\
\hline \multirow[t]{2}{*}{ Age group 40-49 } & 1.23 & 1.206 & 1.22 & 1.27 & 1.191 & 1.133 & 1.1 \\
\hline & {$[0.260]$} & {$[0.248]$} & {$[0.260]$} & {$[0.278]$} & {$[0.251]$} & {$[0.231]$} & {$[0.225]$} \\
\hline \multirow[t]{2}{*}{ Age group 50-59 } & 0.87 & 0.869 & 0.854 & 0.893 & 0.826 & 0.754 & 0.704 \\
\hline & {$[0.202]$} & {$[0.199]$} & {$[0.203]$} & {$[0.214]$} & {$[0.191]$} & {$[0.163]$} & {$[0.157]$} \\
\hline \multirow[t]{2}{*}{ Age group $\geq 60$} & 1.063 & 1.054 & 1.034 & 1.104 & 1.003 & 1.006 & 0.918 \\
\hline & {$[0.239]$} & {$[0.237]$} & {$[0.245]$} & {$[0.260]$} & {$[0.220]$} & {$[0.245]$} & {$[0.225]$} \\
\hline \multirow[t]{2}{*}{ Health status } & 1.109 & 1.103 & 1.112 & 1.132 & 1.135 & 1.054 & 1.095 \\
\hline & {$[0.198]$} & {$[0.200]$} & {$[0.197]$} & {$[0.205]$} & {$[0.210]$} & {$[0.195]$} & {$[0.210]$} \\
\hline \multirow[t]{2}{*}{ Married/Cohabiting } & 1.251 & 1.234 & 1.252 & 1.242 & 1.205 & 1.22 & 1.164 \\
\hline & {$[0.264]$} & {$[0.264]$} & {$[0.264]$} & {$[0.248]$} & {$[0.240]$} & {$[0.258]$} & {$[0.228]$} \\
\hline \multirow[t]{2}{*}{ Currently working } & 0.864 & 0.878 & 0.861 & 0.866 & 0.816 & 0.88 & 0.844 \\
\hline & {$[0.164]$} & {$[0.167]$} & {$[0.166]$} & {$[0.168]$} & {$[0.142]$} & {$[0.166]$} & {$[0.153]$} \\
\hline
\end{tabular}




\begin{tabular}{|c|c|c|c|c|c|c|c|}
\hline & {$[0.005]$} & {$[0.005]$} & {$[0.005]$} & {$[0.005]$} & {$[0.005]$} & {$[0.005]$} & {$[0.005]$} \\
\hline \multirow[t]{2}{*}{$\%$ with secondary education in hh } & 0.999 & 0.998 & 0.999 & 0.999 & 0.999 & 0.999 & 1.000 \\
\hline & {$[0.002]$} & {$[0.002]$} & {$[0.002]$} & {$[0.002]$} & {$[0.002]$} & {$[0.002]$} & {$[0.002]$} \\
\hline \multirow[t]{2}{*}{ Years of residence } & 0.996 & 0.996 & 0.996 & 0.996 & 0.997 & 0.996 & 0.996 \\
\hline & {$[0.005]$} & {$[0.005]$} & {$[0.005]$} & {$[0.005]$} & {$[0.005]$} & {$[0.005]$} & {$[0.005]$} \\
\hline \multirow[t]{2}{*}{ Own house } & 1.173 & 1.159 & 1.175 & 1.242 & 1.241 & 1.099 & 1.217 \\
\hline & {$[0.330]$} & {$[0.325]$} & {$[0.330]$} & {$[0.352]$} & {$[0.348]$} & {$[0.308]$} & {$[0.341]$} \\
\hline \multirow[t]{2}{*}{ Own land } & 1.213 & 1.223 & 1.213 & 1.159 & 1.208 & 1.253 & 1.209 \\
\hline & {$[0.226]$} & {$[0.224]$} & {$[0.226]$} & {$[0.206]$} & {$[0.238]$} & {$[0.227]$} & {$[0.214]$} \\
\hline \multirow[t]{2}{*}{ House located near coast } & $2.532^{* *}$ & $2.540^{* *}$ & $2.540^{* *}$ & $2.486^{* *}$ & $2.680^{* * *}$ & $2.538^{* *}$ & $2.617^{* *}$ \\
\hline & {$[0.759]$} & {$[0.756]$} & {$[0.773]$} & {$[0.767]$} & {$[0.769]$} & {$[0.765]$} & {$[0.777]$} \\
\hline \multirow[t]{2}{*}{ House located near river } & 1.015 & 1.02 & 1.011 & 1.049 & 1.042 & 1.014 & 1.063 \\
\hline & {$[0.200]$} & {$[0.202]$} & {$[0.202]$} & {$[0.220]$} & {$[0.219]$} & {$[0.213]$} & {$[0.246]$} \\
\hline \multirow[t]{2}{*}{ House located near mountain } & 1.526 & 1.562 & 1.52 & 1.692 & 1.461 & 1.36 & 1.428 \\
\hline & {$[0.821]$} & {$[0.802]$} & {$[0.816]$} & {$[0.904]$} & {$[0.800]$} & {$[0.663]$} & {$[0.6665]$} \\
\hline \multirow[t]{2}{*}{ Area 2} & $0.404^{*}$ & $0.385^{*}$ & $0.398^{*}$ & $0.406^{*}$ & $0.352^{*}$ & $0.386^{*}$ & $0.323^{*}$ \\
\hline & {$[0.178]$} & {$[0.173]$} & {$[0.170]$} & {$[0.184]$} & {$[0.157]$} & {$[0.166]$} & [0.142] \\
\hline \multirow[t]{2}{*}{ Area 3} & 1.026 & 1.014 & 1.016 & 1.071 & 0.907 & 1.051 & 0.949 \\
\hline & {$[0.389]$} & {$[0.382]$} & {$[0.384]$} & {$[0.406]$} & {$[0.314]$} & {$[0.398]$} & {$[0.331]$} \\
\hline$N$ & 1,152 & 1,152 & 1,152 & 1,152 & 1,152 & 1,152 & 1,152 \\
\hline Pseudo $R^{2}$ & 0.058 & 0.059 & 0.058 & 0.066 & 0.066 & 0.066 & 0.080 \\
\hline $\mathrm{AIC}$ & $2,361.5$ & $2,362.5$ & $2,363.2$ & $2,346.4$ & $2,345.5$ & $2,344.2$ & $2,316.9$ \\
\hline
\end{tabular}

${ }^{+} p<0.1,{ }^{*} p<0.05,{ }^{* *} p<0.01,{ }^{* * *} p<0.001$.

Notes: Cell entries are odds ratios with robust standard errors in parentheses. Standard errors are clustered at the village level.

Table 8. Exploring the interplay between education and disaster experience (effects of controls reported)

\begin{tabular}{|c|c|c|c|c|c|c|c|c|}
\hline \multirow[b]{3}{*}{ Years of education } & \multicolumn{4}{|c|}{ Philippines } & \multicolumn{4}{|c|}{ Thailand } \\
\hline & \multicolumn{2}{|c|}{ Preparedness } & \multicolumn{2}{|c|}{ No. of measures } & \multicolumn{2}{|c|}{ Preparedness } & \multicolumn{2}{|c|}{ No. of measures } \\
\hline & $1.087^{*}$ & {$[0.038]$} & $1.085^{* *}$ & {$[0.031]$} & $1.095^{* *}$ & {$[0.035]$} & $1.109^{* * *}$ & {$[0.034]$} \\
\hline Interaction & $0.890^{+}$ & {$[0.063]$} & $0.905^{+}$ & {$[0.047]$} & $4.797^{* * *}$ & {$[2.105]$} & $4.807^{* * *}$ & {$[2.071]$} \\
\hline Age group 30-39 & 0.686 & {$[0.243]$} & 0.904 & {$[0.248]$} & $1.628^{*}$ & {$[0.339]$} & 1.384 & {$[0.332]$} \\
\hline Age group $\geq 60$ & 0.623 & {$[0.318]$} & 0.549 & {$[0.212]$} & 1.16 & {$[0.283]$} & 1.068 & {$[0.243]$} \\
\hline Health status & 1.046 & {$[0.038]$} & $1.061^{*}$ & {$[0.032]$} & 1.082 & {$[0.200]$} & 1.1 & [0.198] \\
\hline Married/Cohabiting & 1.095 & {$[0.184]$} & 1.063 & {$[0.109]$} & 1.231 & {$[0.273]$} & 1.264 & {$[0.270]$} \\
\hline Currently working & 0.998 & {$[0.295]$} & 1.165 & {$[0.248]$} & 0.769 & {$[0.166]$} & 0.845 & {$[0.160]$} \\
\hline Female & & & & & $1.291^{+}$ & {$[0.199]$} & $1.315^{*}$ & {$[0.162]$} \\
\hline Mother has secondary education & 1.073 & {$[0.287]$} & 0.945 & {$[0.176]$} & & & & \\
\hline Father has secondary education & 1.159 & {$[0.242]$} & $1.427^{*}$ & {$[0.247]$} & & & & \\
\hline$\%$ with secondary education in hh & 1.008 & {$[0.005]$} & 1.004 & {$[0.004]$} & 0.999 & {$[0.002]$} & 0.999 & {$[0.002]$} \\
\hline Years of residence & $1.024^{*}$ & {$[0.011]$} & 1.008 & {$[0.009]$} & 0.994 & {$[0.005]$} & 0.996 & {$[0.005]$} \\
\hline Own house & & & & & 1.174 & {$[0.313]$} & 1.206 & {$[0.320]$} \\
\hline Own land & & & & & 1.309 & {$[0.273]$} & 1.219 & {$[0.228]$} \\
\hline House located near coast & & & & & $4.234^{* * *}$ & {$[1.807]$} & $2.593^{* *}$ & {$[0.772]$} \\
\hline House located near river & 0.975 & {$[0.222]$} & 0.941 & {$[0.198]$} & 0.985 & {$[0.217]$} & 1.000 & {$[0.202]$} \\
\hline House located near mountain & $0.685^{+}$ & {$[0.147]$} & 0.847 & {$[0.152]$} & 1.439 & {$[0.737]$} & 1.657 & {$[0.890]$} \\
\hline Area 2 & $1.789^{*}$ & {$[0.511]$} & $2.042^{* *}$ & {$[0.469]$} & $0.391^{*}$ & {$[0.177]$} & $0.405^{*}$ & {$[0.177]$} \\
\hline Area 3 & 1.337 & {$[0.326]$} & 1.36 & {$[0.267]$} & 0.979 & {$[0.373]$} & 1.047 & {$[0.388]$} \\
\hline Observations & \multicolumn{2}{|c|}{872} & \multicolumn{2}{|c|}{872} & \multicolumn{2}{|c|}{1,152} & \multicolumn{2}{|c|}{1,152} \\
\hline Pseudo $R^{2}$ & \multicolumn{2}{|c|}{0.068} & \multicolumn{2}{|c|}{0.035} & \multicolumn{2}{|c|}{0.115} & \multicolumn{2}{|c|}{0.06} \\
\hline AIC & \multicolumn{2}{|c|}{942.6} & \multicolumn{2}{|c|}{$2,604.7$} & \multicolumn{2}{|c|}{$1,324.7$} & \multicolumn{2}{|c|}{$2,358.6$} \\
\hline
\end{tabular}

${ }^{+} p<0.1,{ }^{*} p<0.05,{ }^{* *} p<0.01,{ }^{* * *} p<0.001$.

Notes: Cell entries are odds ratios with robust standard errors in parentheses. Standard errors are clustered at the neighborhood level (PH) or village level (TH). Dummy variables of whether mother and/or father are unknown $(\mathrm{PH})$ are not displayed.

Available online at www.sciencedirect.com

\section{ScienceDirect}

